IFN Working Paper No. 698, 2007

\title{
Political Rents in a Non-Corrupt Democracy
}

Helena Svaleryd and Jonas Vlachos 


\title{
Political Rents in a Non-Corrupt Democracy*
}

\author{
Helena Svaleryd \\ Research Institute of Industrial Economics \\ P.O. Box 55665, 10215 Stockholm, Sweden \\ Helena.Svaleryd@ifn.se \\ Jonas Vlachos \\ Department of Economics, Stockholm University and CEPR \\ 10691 Stockholm, Sweden \\ Jonas.Vlachos@ne.su.se.
}

September 25, 2008

\begin{abstract}
A fundamental problem in all political systems is that the people in power may extract rents to the detriment of the general public. In a democracy, electoral competition and information provided by the media may keep such rent extraction at bay. We develop a simple model where rents are decreasing in the degree of political competition and voter information. In line with our theoretical predictions, we find that both increased political competition and increased local media coverage substantially reduce direct measures of legal political rents among local governments in a non-corrupt democracy (Sweden).
\end{abstract}

JEL classification: D72, H1, H7.

Keywords: Accountability, Political Competition, Media, Political Rents.

${ }^{*}$ We are grateful to two anonymous referees, Robin Burgess, Mike Burkart, Tore Ellingsen, Lars Frisell, Samuel Lee, Erik Lindqvist, Torsten Persson, Anna Sjögren, David Strömberg, Gisela Waisman, Daniel Waldenström and seminar participants at the European Economic Association Congress in Vienna, London School of Economics (STICERD), Research Institute of Industrial Economics, University of Munich, Uppsala University and Stockholm School of Economics (SITE and Department of Economics) for valuable input. John Ekberg, Niklas Hanes, Per Pettersson-Lidbom, Tidningsstatistik $\mathrm{AB}$ and Ingela Wadbring have helped us with various aspects of data collection. Mark Blake has provided editorial support and Jörgen Nilsson, Mikael Ohlsson, Stefan Westerberg and David Zimmerman have provided excellent research assistance. Both authors thank Jan Wallander's and Tom Hedelius' Research Foundations and the Swedish Research Council for financial support. 


\section{Introduction}

A fundamental problem in all political systems is that the politicians and political parties in power may use their positions to further their own interests, rather than the interests of the general public. Depending on the degree of accountability that politicians are facing, it is possible for them to divert public resources, rents, to their own or their parties' pockets. While corruption is the most blatant example of this, the problem is by no means restricted to corrupt regimes. In fact, most theoretical treatments of political agency problems between those in power and those governed are set in a context resembling the workings of modern, well-functioning democracies. In such models, the incentives for politicians to extract rents are shaped by factors such as the degree of electoral competition and voter information. ${ }^{1}$ The central aspect of corruption - that bribes are illegal - is usually not considered. Rather, rent extraction is treated as legal, either by implicit or explicit assumption. ${ }^{2}$

Despite this, most empirical work on rent extraction has dealt with the determinants of corruption, not with legal rents. ${ }^{3}$ The scarce number of empirical papers dealing with more developed and less corrupt economies have, on the other hand, been using measures such as tax rates, public employment and wages, growth promoting policies, and politician quality as proxies for rents. ${ }^{4}$ However, such variables are more closely related to slack and inefficiencies than to rents, per se. In this paper, we empirically analyze the impact of political competition and media coverage on direct measures of political rents among local governments in a mature and non-corrupt democracy, namely Sweden. ${ }^{5}$ We also develop a simple model which allows us to analyze the effects of political competition and voter information within the same framework.

The precise nature of political rents is rarely discussed in the theoretical literature.

\footnotetext{
1 Persson and Tabellini (2000) and Besley (2006) present and discuss several classes of political agency models.

2 Recently, this has started to change. Both Ferraz and Finan (2007) and Waisman (2008) present theoretical models where the illegality of corruption is given special attention.

3 The empirical literature on corruption is huge; see Svensson (2005) for an accessible overview.

4 See Besley and Case (2003) and Besley et al (2005).

5 In 2005, Sweden got a corruption score of 9.2 (out of 10) by Transparency International and was ranked as the sixth least corrupt country in the world.
} 
The most literal interpretation is that rents are monetary transfers in the form of public financing of political parties and excessive wages for top politicians (Persson and Tabellini, 2000 p.8). In the empirical part of the paper, we use data on precisely these variables among Swedish local governments. An important feature of the Swedish system is that both public financial party support and politicians' wages are determined within the local budget and are set by a simple vote in the local council. Moreover, there are no formal restrictions on the level of public financial support that the local politicians can award their parties. ${ }^{6}$ Using these direct and objective measures of political rents, we find that increases in both political competition and local newspaper coverage tend to substantially reduce both types of rents.

It is not obvious that financial party support is a good measure of rents. After all, it is possible that voters have a preference for public sponsoring of political parties. Three results speak against such a public-interest view. First, we find that municipalities systematically structure party support such that it favors the financial interests of the ruling majorities at the expense of the other parties. Second, we find there to be electoral cycles in financial party support: increases in financial party support among local governments facing high competition are relatively low in election years, a finding which is hard to reconcile with the public interest view. ${ }^{7}$ Finally, Besley and Preston (2007) find that political competition is likely to moderate party-specific policy preferences. We, on the other hand, find the same response to political competition among left- and right-wing municipalities, even though left-wing governments on average spend more on financial support to political parties.

Conducting a study of Swedish local governments has several advantages. As Swedish municipalities all work within the same legal and institutional system, we get around many of the problems associated with cross-country studies. Still, local governments

\footnotetext{
6 This said, there are restrictions on how the public support system can be structured. These restrictions basically say that all parties represented in the local parliament must be treated in a fair and equal way. Hence, if party $\mathrm{X}$ is in power, it cannot decide to only give support to party $\mathrm{X}$.

7 Ansolabehere et al (2003) find the degree of competition to be strongly related to campaign spending in US gubernatorial elections. Since the demand for information concerning the political alternatives is presumably higher when competition is high, a similar pattern in public financial support to parties is to be expected - if such spending is mainly due to voter demand.
} 
have considerable fiscal autonomy and powers of taxation, and local newspapers are an important source of information about local politics in Sweden. Therefore, we rely on close to ideal units of observation when trying to isolate the effects of political competition and mass media on rents.

As political competition may be affected by rent extraction, endogeneity is a concern. In the panel analysis, we use the fact that changes in local political competition are partly due to general trends independent of local politics. In the cross-sectional analysis, we use the fact that the current municipal structure was created by a major reform in the early 1970's. A new set of municipalities, without a previous track record of policy making and rent extraction, was thus created. At the same time, political preferences at the local level tend to be stable over time. By aggregating electoral data from the period before the reform to the present jurisdictional level, we construct an instrument for political competition. In line with our theoretical predictions, we find that the IV estimates are larger than the OLS estimates.

This paper adds to the existing literature in several ways, some of which are mentioned above. The basic finding concerning the relation between political competition and accountability corresponds well to previous research. Besley and Case (2003) find that stronger political competition reduces taxes and worker compensation in US local governments. Using US state level data, Besley et al (2005) find that increased political competition leads to higher economic growth, lower taxes, less labor market regulation and politicians of higher quality. Besides using direct measures of rent extraction, our paper differs from previous research by being set in a proportional electoral system without any term limits. Since voters' capacity to hold politicians accountable is generally considered to be lower in proportional than in majoritarian systems, it is interesting in its own right to study accountability in a proportional system. ${ }^{8}$

While the importance of mass media for keeping the public informed about policy has long been recognized, it is not until rather recently that this role has been included

8 For theoretical treatments of the effects of constitutions, see Persson and Tabellini (2000). For empirics, see Persson and Tabellini (2003). Acemoglu (2005) offers a critical review of the latter book. Persson et al (2003) specifically investigate how the electoral system affects corruption. 
in the formal literature on accountability. In an influential paper, Besley and Burgess (2002) find that governments in India are more responsive to their citizens' needs when newspaper coverage and electoral accountability are high. Similarly, Strömberg (1999, 2004) finds that US counties with a broad radio coverage received more relief funds during the New Deal era. More directly related to rent extraction, Reinikka and Svensson (2005) use detailed data from a policy experiment in Uganda to document a strong negative relation between media access and local capture of public funds. The effect of local media on accountability within more developed economies has, up to date, been given less attention. ${ }^{9}$ Our contribution to this literature is to provide such an analysis within a country where freedom of the press is guaranteed.

This paper is organized as follows. Section two presents the theoretical model and the empirical predictions. Section three discusses estimation issues and the data. It also provides a brief description of the Swedish political institutions relevant to this study. Section four presents the results and Section five concludes the paper.

\section{A Simple Model}

Political rents is a key concept in many models of political agency. ${ }^{10}$ These rents are resources being transferred from voters to politicians and from the voters' perspective, these rents are pure waste. In this section, we present a simple model where voter biases reduce political competition which gives room for rent extraction. As a novel feature of the model, we allow for part of the electorate to be uninformed about the level of rents. $^{11}$

In the model, voters are backward looking and decide whether to vote for an incumbent party. From voters' current income $I$ (normalized to one), rents, $r \in[0,1]$, can be

\footnotetext{
${ }^{9}$ Several papers using cross-country data document a positive relation between free and developed media and measures of good governance (e.g. Ahrend, 2002; Brunetti and Weder, 2003; Adserà et al, 2003).

10 See Persson and Tabellini (2000) and Besley (2006) for thorough treatments of several classes of political agency models.

11 With perfect political competition and well informed voters, rents are usually driven down to zero (e.g. Wittman, 1989).
} 
extracted. The incumbent party only cares about rents and about being reelected. The timing is as follows: First, the incumbent sets the level of rents, taking their negative effect on the reelection probability, $P(r)$, into account. Based on the level of rents, the media decides whether to report on them. The probability of reporting is assumed to be $\pi(r)=r$. The intuition behind this assumption is that it is less costly for the newspaper to dig out information about rents when these are high. Alternatively, the newspaper considers that subscribers are more interested in reading about large than small rents. If media reports about rents, information about their level is spread to the exogenously set share $M \in(0,1)$ who is subscribing to a newspaper. We assume that those who read the newspaper derive utility $v$ from doing so. In other words, those who read the newspaper do so for reasons unrelated to policy issues. Finally, voters cast their votes based on net income and the information about rents received through media reporting.

Formally, the incumbent chooses $r$ to maximize the following expression:

$$
r+P(r) R
$$

where $R$ is the level of exogenous office rents that accrue to the party in power. The value of holding office is exogenous from the current level of rent extraction.

The electorate consists of a continuum of voters, $i$. In line with the probabilistic voting model by Lindbeck and Weibull (1987), voters are assumed to have preferences over non-policy related aspects of the parties. The average popularity of the incumbent party, $d$, is uniformly distributed over $\left[-\frac{1}{2 z}, \frac{1}{2 z}\right]$. The higher the value of $z$, the higher is the density of swing voters and the more competitive is the election. Voters vote in favor of the incumbent if their reservation utility is above a certain threshold level. ${ }^{12}$ The reservation utility $w_{i}$ is assumed have zero mean and be uniformly distributed on support $\left[-\frac{1}{2}, \frac{1}{2}\right]$. Since both the individual reservation utility and the average popularity of the incumbent are uniformly distributed, there is uncertainty about both the bias and the identity of the median voter. Thus, the reelection probability becomes a

\footnotetext{
12 The opposition party has similar preferences as the incumbent party. Thus, the only reason for voters not to reelect the incumbent is to punish rent extraction ex post.
} 
smooth function of rent extraction. ${ }^{13}$

When the incumbent party decides on the level of rent extraction, it knows the distributions of the reservation utility and the popularity parameter, but not their realized values. Apart from net income and the utility from reading the newspaper, voters have a direct dislike of rents, $\beta r$, provided that they are informed about them.

An uninformed voter will vote for the incumbent party if her utility is higher than her reservation utility $w_{i}$, i.e. if

$$
u^{U}=I-r+d=1-r+d \geqslant w_{i}
$$

Correspondingly, an informed voter will be in favor of the incumbent if

$$
u^{I}=I-r+d+v-\pi(r) \beta r=1-r+d+v-\beta r^{2} \geqslant w_{i}
$$

The reelection probability for the incumbent is the probability that the share of voters voting for the incumbent is larger than $\frac{1}{2}$. The incumbent sets $r$ to maximize (1). By inserting (2) and (3) into (1), and taking expectations, the assumptions concerning the distribution of the reservation utility give the incumbent the following expression to maximize with respect to $r:^{14}$

$$
r+P(r) R=r+\left(\frac{1}{2}+z\left[1+M v-r-M \beta r^{2}\right]\right) R
$$

The first-order condition gives the following optimal value of $r$ :

$$
r^{*}=\frac{1-z R}{2 z R M \beta}
$$

Since rents are non-negative, we know that $1 \geq z R$. Therefore, we can sign the FOC with respect to the main variables of interest, $z$ and $M$.

\footnotetext{
13 This is a general feature of probabilistic voting models.

14 To see this, notice that the reelection probability is $\operatorname{Pr}\left(\frac{1}{2}+M u^{I}+(1-M) u^{U} \geq \frac{1}{2}\right)$. Therefore, $P(r)=\operatorname{Pr}\left(d \geq M \beta r^{2}-1-M v+r\right)$ and hence, $P(r)=\frac{1}{2}+z\left[1+M v-r-M \beta r^{2}\right]$.
} 


$$
\begin{aligned}
\frac{d r^{*}}{d z} & =\frac{d\left(\frac{1-z R}{2 z R M \beta}\right)}{d z}=-\frac{1}{2 R \beta z^{2} M}<0 \\
\frac{d r^{*}}{d M} & =\frac{d\left(\frac{1-z R}{2 z R M \beta}\right)}{d M}=\frac{1}{2 R \beta z M^{2}}(R z-1)<0 .
\end{aligned}
$$

The derivatives in (6) show that rents are decreasing in both $z$ and $M$. In other words, both increased political competition and increased media coverage help keeping rent extraction at bay. Despite the simplifying assumptions in this model, the result that rents are decreasing in competition and media coverage is quite general. Both high competition and increased news coverage make voters respond more to the same level of rent extraction. Since responsive voters punish the incumbent by reducing the reelection probability, this keeps rents low.

\section{Empirical strategy, data and measurement issues}

Our main units of analysis are Swedish municipalities, but we also make use of countylevel data. In this section, we describe the features of the institutional environment. We then outline the empirical strategies employed when testing the predictions regarding political competition and voter information on rent extraction. Finally, measurement issues are discussed and the data is presented.

\subsection{The Institutional Environment}

The Swedish political system consists of three levels of government: central government, counties and municipalities. As mentioned in the Introduction, Swedish local governments have the constitutional right of self-governance; they set their own income taxes and they decide on their own budget. That the autonomy from central government is not only formal has been shown in several empirical studies on the effects of local 
government on policy (e.g. Pettersson-Lidbom 2001, 2008). Moreover, governance of local governments is of real importance in the Swedish system. Total spending in 2003 was 17 percent of GDP at the municipal level and 8 percent of GDP at the county level.

Today, the main areas of responsibility of the municipalities are schooling, child care and care of the elderly, while the main responsibilities of the counties are health and medical care. In 1970, local governments were given the legal right to dedicate resources from the local budget to the parties represented in the elected council. The primary focus of this study is this local public financial support to political parties. Since this opportunity was introduced, local public support to the political parties has increased in both municipalities and counties. In 2003, the municipalities spent around 300 million and the counties around 200 million Swedish kronor (a total of about 55 million Euros) on party support. While these sums are trivial as compared to total expenditures (or GDP), local party support is an important source of revenue for the parties. In fact, more than half of the total revenues come from local public support from municipalities and counties (Svenska Dagbladet, 2004). ${ }^{15}$

The level of public support to political parties is decided by the elected representatives themselves in the budget, after a vote in the local council. In effect, it is therefore the ruling majority that decides on the size of the monetary support. Initially, the only restriction on the construction of the support was that all parties represented in the council should be included. Since 1992, there has been an additional requirement that parties should be treated equally. ${ }^{16}$ An interesting feature of the system is that all parties receive the support - not only the winning coalition. Local governments also decide on a sharing rule that includes a base (per party) and a variable (per seat) financial support and there is considerable variation in their relative levels. One part of our analysis will exploit this variation to see if the sharing rule systematically benefits

\footnotetext{
15 Party financing in Sweden is surprisingly nontransparent. According to the estimates in Svenska Dagbladet (2004), another 250 million SEK of the party revenues are public party support determined by the national parliament. Other contributions (including membership fees) add up to 230 million SEK.

16 What "equally" means is not defined. In effect, it means that two parties with equal representation in the local parliament receive the same level of support. The actual sharing rules differ substantially between municipalities.
} 
the ruling majority. Finally, we study the wages paid to politicians in municipalities as an alternative measure of rents. Wages are also determined by the local council and are part of the municipal budget.

Some words about the political system are of relevance here. Sweden has a parliamentary system with proportional representation. As is common in this type of system, a number of parties are represented in the elected assemblies. Although there are several parties, there is a quite clear dividing line between left-wing and right-wing parties leading to a fairly stable two-bloc system. The Social Democrats, the Left Party and the Green Party are considered to constitute the left-wing coalition. ${ }^{17}$ The right-wing coalition consists of the Conservatives, the Liberals, the Centre Party, the Christian Democrats and New Democracy (only in the 1992-1995 period). Nationally active parties traditionally play an important role in Swedish politics and there are few local parties of importance at the county and municipality level. At both levels of government, elections are held on the third Sunday in September and there are no interim elections.

Swedish newspapers are of a highly local nature. In what might be an exception in comparison to some other parts of the world, local newspapers usually cover local politics on a regular basis. While a few papers (Dagens Nyheter and Svenska Dagbladet) are being read nationally, they have very limited coverage outside the Stockholm (the capital) region. ${ }^{18}$ Printed media is important for getting access to information about politics and policy in Sweden. According to surveys of the Swedish electorate, voters reading the local newspapers are generally much better informed than other voters. ${ }^{19}$

\footnotetext{
17 The Green Party entered the national parliament after the election in 1988 . While this party has claimed to stand independent from both the left- and the right-wing blocs, they are best classified as left wing. The Green Party has, for example, only once supported a right-wing coalition in any of the counties. Further, in a detailed survey of municipal majorities after the 1994 election, it was found that it was four times more likely to support a left-wing coalition than a right-wing coalition (Kommunaktuellt, 1995). In addition, after the elections in 1998 and 2002, it has been part of the left-wing coalition supporting the Social Democratic minority government in the national parliament. Finally, ever since the Green Party entered the political arena in 1982, voters in general have placed the Green Party on the left-hand side of the political spectrum, and the voters for the Green Party have placed themselves on the same side (Holmberg and Oscarsson, 2004; Tables 5.1 and 5.2).

18 These two papers also cover local politics in the Stockholm area but not in the rest of the country.

19 Holmberg and Oscarsson (2004; Table 9.5).
} 


\subsection{Empirical strategy}

The theoretical framework shows that stronger political competition should reduce political rents. We will study both the long-term effects using cross-sectional data and the impact of changes in competition and media coverage using panel data. Since the variation in political competition is larger between than within municipalities, a cross-sectional approach is informative. However, a concern about omitted variables motivates the use of panel data.

Using cross-sectional data, the baseline regression model takes the form:

$$
\begin{aligned}
\text { Political Rents }_{i}= & \alpha+\beta_{1} \text { Political competition }_{i}+\beta_{2} \text { Voter information }_{i} \\
& +\gamma \text { Controls }_{i}+\epsilon_{i},
\end{aligned}
$$

where Political Rents $s_{i}$ is our measure of rent extraction by local government $i, \alpha$ is a constant and Political competition cis $_{i}$ our measure of political competition. The model also makes predictions concerning the impact of voter information on political rents. Therefore, we introduce the variable Voter information, , proxied by local newspaper coverage, as a measure of municipal-level information on political rent extraction. Controls $_{i}$ is a vector of control variables such as population size, income per capita, and the share of the population with higher education. Finally, $\epsilon_{i}$ is the usual i.i.d. error term. A thorough discussion of the choice of proxies and data is provided in the next section.

To analyze the within municipal determinants of rent extraction, we make use of panel data that allows us to control for municipal-level fixed effects $\left(\mu_{i}\right)$ and fixed time effects $\left(\lambda_{t}\right)$. When running panel regressions, we cluster the standard errors at the municipal (or county) level to account for serial correlation within each legislative unit. The estimating equation in this case is: 


$$
\begin{aligned}
\text { Political Rents }_{i t}= & \mu_{i}+\lambda_{t}+\beta_{1} \text { Political competition }_{i t}+ \\
& \beta_{2} \text { Voter information } \\
\text { it } & +\gamma \text { Controls }_{i t}+\epsilon_{i t} .
\end{aligned}
$$

To widen our understanding of the impact of political competition on rent extraction, we also analyze whether political competition is an important determinant of how rent extraction responds to income shocks. Empirically, we then interact our measure of political competition with municipal per capita income in a fixed effects setting, such as (8).

Naturally, endogeneity is a concern in such an empirical study. Theory tells us that low political competition will push rents upwards. High rents will, in turn, induce some voters to vote for the opposition party. Since political competition is measured after rent extraction has taken place, measured political competition will seem to be tougher than the actual underlying degree of competition. For this reason, we expect the coefficient $\beta_{1}$ to be biased towards zero. Another possibility (not based on our theoretical model) is that political rents help the incumbent preserve the status quo. If this is the case, we would tend to exaggerate the effects of competition on rents. For these reasons, we discuss below how to instrument for political competition in a cross-sectional and a panel setting.

Although the question of reverse causality is less severe for local newspaper coverage, a drawback of this study is that we have no credible instrument for coverage. Our major concern is, however, that an omitted variable, such as the general knowledge level, affects both coverage and political rents. To limit this problem, we include other variables that should pick up any such effects.

\subsection{Data and measurement issues}

The number of municipalities has grown from 278 in 1974 to 290 in 2004 . In our data set, there is a maximum of 254 municipalities since we drop those that have split or merged over the years. Depending on which instrument we use, a couple of municipalities are 
omitted due to data constraints. The main sources of data are the Swedish Association of Local Authorities and Regions and Statistics Sweden. Although municipalities are the main objects of study, we also make use of county-level information. Today, there are 20 counties, 18 of which have existed throughout our sample period. The remaining two were created in 1997-1998 through the amalgamation of five different counties. Therefore, we have a maximum of 23 different county-level units of observation. For a detailed description of the data sample and sources for the individual variables, see the Data Appendix and Appendix Table A.1.

\subsubsection{Measures of rents}

We will use the per capita local public financial support to political parties, Party Support, as our main measure of political rents. As argued in the Introduction, this variable is close to a literal interpretation of "rents" in the theoretical literature. Municipallevel data on Party Support is available for every post election year from 1974 to $2003 .{ }^{20}$ Even though data is only available for these years, the level of party support is determined in the annual budget and may thus change during the election cycle. Part of the analysis will also be undertaken at the county level for which annual data is available.

The major drawback of this variable is that it does not capture all political rents, while the main advantage is that the measurement problems are limited. Another concern is that financial party support might be viewed as something voters actually require. The main reason for this would be informational - voters want all parties to have the means of providing information about their policies and conduct informative election campaigns. However, it is reasonable to expect demand for such information to be especially high when competition between the political alternatives is fierce - if voters have no intention of changing the party for which they vote, they do not need to become informed about the alternatives. ${ }^{21}$ This would lead us to find a positive effect

\footnotetext{
20 Elections were held in 1973, '76, '79, '82, '85, '88, '91, '94, '98, and 2002. In the mid-1990's, the authority responsible for gathering this data was changed. Due to this change, data was obviously misreported in some municipalities and for this reason, we drop 11 municipalities. See details in the Data Appendix.

21 Ansolabehere et al (2003) find that the degree of both inter- and intra party competition is
} 
of political competition on party support. In Section 4.2, we address this concern and show results that are consistent with the view that Party Support should indeed be viewed as a measure of rents.

Our second measure of political rents is the wage paid to the highest ranking fulltime employed politician. We make use of two sources to construct this variable, one from 1974-1989 which only reports the level of wages and one from 1990-1999 which also reports the age and gender of the politician. Although wages are also determined by the local council and are monetary transfers from tax payers to politicians, we do not consider them to be as good a measure of political rent as party support. There are several reasons for this. First, voters may want to pay their politicians high wages in order to give them incentives to act in the interest of the electorate. Second, wages may affect candidate selection and thereby affect policy. ${ }^{22}$ Thus, the motive for high wages may not be rent extraction but may reflect the electorate's demand for high quality performance. Finally, Sweden has a party dominated political system where the leading representatives are selected through the internal nomination processes within each party. The parties, in turn, have little to gain from extracting rents by raising personal wages. However, as the leading politician of a party can have a very strong position and may use this to further his/her own interest, we include this as an alternative measure of rent extraction. ${ }^{23}$

Table 1 shows summary statistics for all variables used in the study. Notice that all values are deflated into 2000 year prices. Over the period, average (unweighted) financial party support was almost 32 Swedish kronor per capita with a large variation both across municipalities and over time. In 2003, the municipality with the lowest level of financial party support, Söderköping, only spent 8 kronor per capita on party support, whereas Haparanda with the highest spending allocated 121 kronor per capita to party support. As can be seen in the third row of Table 1, there is also substantial

\footnotetext{
strongly related to campaign spending in US gubernatorial elections.

22 For a discussion of the effect of pay on politicians, see Besley (2004).

23 In a study of US gubernatorial wages, Di Tella and Fisman (2004) find support for the idea that wages are partly determined by rent extraction motives.
} 
variation in our second proxy for rents, politicians' wages.

\section{TABLE 1 HERE}

\subsubsection{Measuring political competition}

Several different measures of political competition have been used by other researchers. ${ }^{24}$ Here, we follow much of the literature and use the absolute difference between the leftwing and the right-wing bloc. Political competition is defined as 1 minus the absolute difference between blocs. The average level of competition is 0.81 which means that, on average, the majority bloc has 60 percent of the votes. While this may seem like a comfortable majority, in 25 percent of the municipalities the leading majority has less than 53.5 percent of the votes. The main drawback of this measure is that there are no watertight locks between the political blocs as we define them. In some municipalities, parties form coalitions across the traditional right- and left-wing boundaries of Swedish politics, which introduces some noise into this measure.

The absolute value of the difference between the political blocs is easily calculated and it is a good measure of swing voters, provided that the distribution of ideological preferences is symmetric, single peaked, and only two parties are competing for power. Since these assumptions do not necessarily hold, we use the cut point density measure, Cutpoint density, derived by Johansson (2003) to check the robustness of the main results. $^{25}$ Johansson estimates the number of swing voters using factor analysis and a kernel density estimator using data on ideological preferences from the large scale Swedish election surveys conducted in connection with the 1991 and 1994 elections. Using the attitudes conveyed by responses concerning the voters' feelings towards political parties and politicians, a distribution of preferences at the constituency level is

\footnotetext{
24 Besley and Case (2003) provide a comprehensive survey of measures of political competition. In their study of the effect of political competition on policy in US states, they use a measure based on the distance from 0.5 in the fraction of seats held by one party. Dahlberg and Mörk (2006) use the absolute distance between the left- and right-wing blocs, and a measure of party fragmentation in a study of bureaucrats' wages in Swedish local governments.

25 We are grateful to Eva Mörk (previously Johansson) for sharing her data with us.
} 
derived. This way, the strength of ideological preferences over the full distribution of voters is calculated to derive the density of potential swing voters in each constituency. As there are several municipalities in each constituency, this distribution is assumed to be the same for all municipalities in each constituency. The actual position of each municipality in the preference distribution is then derived using the municipal level election results for the previous election. ${ }^{26}$ These measures overlap with the rest of the data for the time periods 1992 and 1995.

\subsubsection{Instrumentation}

As discussed above, endogeneity may be an issue when using a measure of political competition such as ours. Therefore, we want to construct an instrument reflecting the underlying degree of political competition, but which is unaffected by the current level of rent extraction. To achieve this, we make use of the fact that the current municipal structure did not exist prior to the early 1970's. The present structure was created when a major municipal reform led to a reduction in the number of municipalities from about 1000 to $278 .^{27}$ The main objective of the reform was to create more efficient administrative units, an important issue since the municipalities were to handle much of the rapidly growing public service provision. The reform also aimed at maintaining local democracy and local self-government. For these purposes, it was important that the municipalities were sufficiently large to have a stable tax base and the capacity to implement policy. Originally, the amalgamation of municipalities was meant to be voluntary, but since the process was slow, the national parliament decided to force the new structure onto the municipalities in 1969. In the reform process, a unified type of municipalities with clearly defined responsibilities replaced the previously existing three types of municipalities. ${ }^{28}$

\footnotetext{
26 There are 28 constituencies in Sweden. Each municipality belongs to one of these. See Johansson (2003) for details concerning the construction of this measure.

27 An earlier reform, in 1952, reduced the number of municipalities from 2498 to 1037 (Gustafsson, 1978).

28 For a thorough discussion of the motivation behind the reform, see SOU (1961). Gustafsson (1980) has analyzed the reform from a political science perspective.
} 
We use the voting pattern from the national (rather than local) elections in 1968, i.e. before the amalgamation of municipalities, and aggregate these to the current municipal structure to create the instrument polcomp68. Since the current municipal structure did not exist before the reform, instruments based on election results prior to this reform should reflect underlying political sympathies rather than post-reform policy making. At the same time, voting patterns are quite stable over time, making the instrument a good predictor of future election results.

Naturally, rent extraction could have existed even under the previous municipal structure. However, the reform was motivated by the radical increase in municipal responsibilities during the 1970's and thus also the size of the local budget. With the reform came also the possibility for local governments to hand out public party support and leading politicians began to be paid wages for holding office. The larger municipal units that were created are also likely to have made the monitoring of local politicians more difficult. Therefore, it is fair to say that the reform increased the scope for rent extraction quite dramatically. Moreover, since there was a fundamental change in the municipal structure, political competition may now be very different from the situation before the reform. For these reasons, an instrument based on election results prior to the municipal reform should reflect underlying political sympathies that are less affected by rent extraction than the current degree of political competition.

As it is time invariant, polcomp68 does not work in a panel setting, for which we need a time varying-instrument. To construct such an instrument, we use the fact that voter movements between parties are to a some extent due to general trends, independent of local politics. For example, the actions of the national government, or governments in other countries, may affect the voting pattern at the local level for reasons that are completely unrelated to local politics. These trends can increase or decrease local competition, depending on which parties are in power locally. Therefore, we use the national election results in the municipalities bordering a municipality to capture the exogenous variation in local political competition. This means that if the left-wing bloc increases its vote share in a neighboring municipality, this is associated 
with a reduction in political competition if a municipality is run by left-wing parties, but associated with an increase in competition if it is run by the right-wing bloc. We create the instrument blocdiff as the average difference expressed in percent in bordering municipalities between the left-wing (right-wing) and right-wing (left-wing) bloc in municipalities governed by a left-wing (right-wing) majority.

The identifying assumption is that the variation in election outcomes among neighboring municipalities is orthogonal to rent extraction in a particular municipality. Thus, general changes in the preferences of the electorate are assumed not to be affected by rent extraction in a particular municipality. In a cross-sectional setting, however, the geographical concentration in preferences results in correlation between municipalities in political competition and therefore, correlation in rent extraction.

\subsubsection{Media}

According to the model, voter information about rents is important for rent extraction. Our proxy for voter information about local politics is the household coverage ratio of local newspapers. The Swedish local media markets are naturally connected to the municipal structure. While a number of newspapers have coverage in several municipalities, most people within a municipality tend to read one or a couple of local newspapers.

Data describing coverage and political color of all local newspapers is provided by Tidningsstatistik AB. This company gathers detailed newspaper data to facilitate the sale of advertisements across Sweden. Using this data, we derive the variable coverage as the sum of household coverage (percent of households buying the paper) of local newspapers that have a coverage of at least 10 percent and are published at least twice a week.

\subsubsection{Control variables}

Further, to isolate the effects, we control for a number of other factors. Population is the log of population, included to capture effects such as economies of scale in running 
a political party. Income is the log of income per capita, included to account for the amount of possible rent extraction, and for differences in voter preferences. Leftwing is defined as the left-wing vote share. This is included to account for differences in the relative dislike of rents among voters. To rule out that the media coverage variable picks up effects of having a more well educated population, we also include the share of inhabitants with higher education, high edu. This variable is only available from 1985 and onwards and is therefore not included in all specifications. When studying the determinants of politicians' wages, we also include a dummy, gender, which takes on the value of one if the politician is a woman as well as the politician's age (and age squared). Further, to adjust for cost of living differences, we control for average house prices.

\section{Empirical results}

Our main empirical predictions are that high political competition will tend to reduce public financial support for political parties and politicians' wages. Further, we expect high local media coverage to reduce these rents. As can be seen in Table 2, there is a statistical significant correlation of -0.20 between public financial support for political parties and our main variable measuring political competition, political competition. ${ }^{29}$ The correlation between public financial support and cutpoint density is -0.25 . The correlation is close to zero between politicians' wages and political competition, while it is -0.15 for cutpoint density.

For local newspaper coverage, the correlation is -0.25 for party support and -0.32 for wages. Thus, the raw correlations point in the direction indicated by theory. Political competition seems to be stronger in municipalities with a larger population and there is no correlation with average educational attainment. The instruments polcomp68 and blocdiff are strongly correlated with the measures of political competition. The relation between coverage and other variables is more surprising, especially the negative corre-

\footnotetext{
29 This negative relation is rather smooth which can be shown by running a non-parametric kernel regression.
} 
lation between media coverage and both income per capita and the share of inhabitants with a high education. There is no significant correlation between our measures of political competition and media coverage.

\section{TABLE 2 HERE}

Before we move on to the formal empirical analysis of political competition and rent extraction, it is illustrative to graphically depict the evolution of municipal- and countylevel party support over time. We divide the regions into more or less competitive groups. For municipalities, we see that party support is substantially higher in the group where the time period average level of political competition is above the 75 th percentile than in the group below the 25 th percentile. For counties, we have detailed data on actual majorities rather than the proxy used for municipalities. In about half of the counties, at least one party has been part of the ruling majority throughout the time period. Figure 2 clearly shows how there has been a substantially larger increase in party support among those counties as compared to the reference group. ${ }^{30}$

\section{FIGURES 1 AND 2 HERE}

We start by analyzing the relationship between political competition and financial party support. Then, we turn to a discussion of whether financial support to political parties should really be viewed as rents. Finally, we move on to investigate the relation between political accountability and politicians' wages.

\subsection{Political accountability and financial party support}

In Table 3, we see that the prediction regarding the relation between political competition and financial party support finds substantial support in the data.

In the first column, using the variable political competition to measure political competition, we find a highly significant negative effect of competition on party support,

\footnotetext{
30 We have estimated if the change in party support over the whole time period is significantly related to the average level of political competition (including covariates). This is indeed the case, regardless of whether we measure competition by the difference between the political blocs or by an indicator for one party always being in the majority.
} 
using cross-sectional data from 2003. ${ }^{31}$ A coefficient of -15.9 means that by increasing political competition by one standard deviation, rents are reduced by 2.3 Swedish kronor per inhabitant, or 6.2 percent as compared to the mean level of rents. By moving from the lowest to the highest value of political competition in our sample, rents are reduced by 11.7 kronor per inhabitant (32 percent as compared to mean rents).

In column two, we instrument for political competition using political competition in the 1968 parliamentary election (polcomp68). The F-test (101.98) from the first-stage regression indicates that the instrument is very strong. Consistent with our theoretical prediction that the OLS estimates are biased towards zero, we find that the size of the effect of political competition is larger when using IV. A standard deviation increase in our competition measure reduces party support by 3 Swedish kronor or 8.4 percent for the municipality with average political competition. This indicates that rents are indeed pushed up in such a way that measured political competition is higher than the underlying degree of competition. Thus, the political parties appear to be ready to lose some votes to gain higher rents.

The other explanatory variables in columns one and two do not seem to affect the level of party support. The exception is the share of left-wing votes which is associated with higher rents. This result could either indicate that left-wing voters are less reluctant to give public financial support to political parties, or that left-wing parties are more inclined to extract this type of rent.

In columns three and four, we use our other measure of political competition, cutpoint density, for the year 1995. ${ }^{32}$ The pattern from regressions one and two repeats itself: the OLS estimates are highly significant and the point estimates are even larger when using IV. The size of the effect is somewhat larger as compared to political competition: a one standard deviation increase in the independent variable implies a decrease in party support of between 3.5 (OLS) and 5.6 (IV) Swedish kronor for cutpoint density (i.e. between 10 and 16 percent as compared to the sample mean).

\footnotetext{
31 If we use the average level of political competition throughout the sample period, we get somewhat stronger results.

32 Political competition is also highly significant for 1995.
} 


\section{TABLE 3 HERE}

While our instrument is likely to be valid regarding direct reverse causality from rents to political competition, we cannot rule out that the results suffer from an omitted variable bias. In the next four columns of Table 3, we exploit the panel dimension of the data and introduce municipal and time-fixed effects to control for unobserved heterogeneity. For the variable political competition, used in column five, we have a long panel. While the point estimate of political competition remains negative, it is not statistically significant at conventional levels. In the next column, we instrument for political competition using the changes in popularity of the two blocs in the bordering municipalities (blocdiff). The effect of political competition is now much stronger and statistically significant. In fact, the point estimate in the panel IV-specification is strikingly similar to the cross-sectional IV-estimate although the size of the standardized effect is somewhat smaller. Using the estimate in column six, a within municipality standard deviation increase in political competition increases party support by 1.8 Swedish kronor or about 5.8 percent.

For our other measure of political competition, cutpoint density, data is only available for two time periods, 1992 and 1995. Keeping this limitation in mind, the results in column seven show that an increase in the density of swing voters is significantly associated with a reduction in rent extraction. Instrumenting for political competition does not change the result (column eight). As is true for all specifications in Table 3 , the estimated effect is larger using IV.

\subsubsection{Adding media}

In this section, we add mass media coverage to the analysis. In the first two columns of Table 4, local newspaper coverage is added to the basic OLS and IV cross-sectional specifications. The point estimate is negative and statistically significant, indicating that local media does indeed play a role in reducing political rent extraction. A coefficient of about -0.13 means that by increasing media coverage by one standard deviation, 
rents are reduced by 2.1 kronor. The point estimate of political competition is somewhat increased by the inclusion of coverage. It is useful to note that including political competition and coverage improves the fit of the regression from an R-squared of 0.181 to 0.208 , i.e. by $16 \%$.

\section{TABLE 4 HERE}

In columns three and four, we run panel regressions including municipal and time period fixed effects. The impact of media coverage is still negative and highly statistically significant after taking the fixed effects into account. As in Table 3, the estimated effect of political competition is negative both in the OLS and IV estimations, but only statistically significant using IV.

Finally, we analyze the hypothesis that municipalities with different degrees of political competition respond differently to income shocks. Specifically, in columns five amd six, we interact political competition with income. Looking at the IV-estimates in column six, we find some indication of the effect of an increase in income on public party funding being larger in municipalities with a relatively low level of political competition. The point estimates are quite imprecisely estimated, however, thus making it hard to gauge the size of this effect.

We have also analyzed other dimensions of media coverage, such as the political affiliation of the major newspaper, the presence of more than one local newspaper, and the concentration of the local newspaper market. ${ }^{33}$ None of these variables turn out to have a significant effect on the level of rents. Perhaps most interesting, we find that whether or not the leading newspaper and the ruling majority are ideologically aligned does not appear to be of any importance for the level of rent extraction. These results are not presented in order to save space.

\footnotetext{
33 The impact of the media market structure on monitoring efficiency and potential reporting biases is discussed in Djankov et al (2003), Mullainathan and Shleifer (2005) and Besley and Prat (2006).
} 


\subsection{Is public financial party support really rents?}

The results in the previous section are consistent with theories linking political rents to political competition. However, it is not obvious that public financial party support is a good measure of rents. After all, it is possible that voters have a preference for public sponsoring of political parties. In this section, we provide evidence that excessive public financial support to political parties is best viewed as rents. At the same time, we will present further results on the effects of competition on the structure of public support and the timing of changes in this variable. First, we show that also the sharing rule of public support to parties depends on the party structure in the municipality. Specifically, it does so in a way consistent with the view that the ruling majority furthers its own interest at the expense of the other parties. Then, we show that the timing of increases in financial party support is inconsistent with a public interest view of those financial transfers. Finally, we show that the response to high competition is similar in municipalities dominated by left- and right-wing parties, indicating that the results cannot be readily explained by differences in preferences across voters.

\subsubsection{The structure of financial party support}

The municipality does not only decide on the size of public financial support to parties, but also on the algorithm, or sharing rule, determining how much each party in the municipality will receive. Thus, there are incentives to construct the sharing rule in such a way that it benefits the party in power at the expense of the other parties in the local council. Most municipalities give the party support in two parts: a base sum to each party and a variable part depending on the number of seats the party has in the local council. Our hypothesis is that if parties benefit themselves, we should see a larger support per seat, relative to the base sum per party, in municipalities where there is a dominant large party or a concentrated party structure.

In order to study if this is the case, we have collected data on the exact construction of party support in the municipalities in 2003 through a survey. 207 out of 290 municipalities responded to our questionnaire. From this data, we construct a variable 
describing the size of the base (per party) support relative to the seat (per seat) support. If the variable base/seats takes a high value, it implies that there is a small party bias in the construction of the sharing rule. If it takes a low value, the opposite applies. As can be seen in Table 1, there is substantial variation in the structure of party support across municipalities. To measure the party structure, we construct the dummy variable own majority that takes the value of one if a single party has a majority of the seats in the local council, and herfindahl, which is the Herfindahl index of parties in the local council.

The hypothesis is that both our measures of a concentrated party structure should have negative effects on the base/seats variable. In the first two columns of Table 5, we see that both herfindahl and own majority indeed have the predicted effects on the structure of party support. The effects are highly statistically significant at the one-percent level. ${ }^{34}$

It is not obvious which, if any, control variables should be included when estimating the determinants of the sharing rule. We have run regressions including the total number of seats in the council, the number of parties represented in the council, income per capita, the size of the population and population density. The main results are unaffected by the inclusion of these control variables, however. ${ }^{35}$

Due to the richness of the data, we are able to more closely investigate which political bloc and parties are more sensitive to political competition. In column 3 , we interact the measure of party structure, herfindahl, with majority bloc to investigate if there are any differences between the left- and right-wing blocs. According to the results, there are no such differences. To further investigate this issue we construct measures of the party structure within party bloc: Herf. in left (right) majority is the Herfindahl index of parties within the left (right) bloc when the left(right) bloc is in majority. For the municipalities with no obvious majority, we use the Herfindahl index of parties in the local council, Herf. when no left/right majority. The results presented in column 4 show

\footnotetext{
34 The result remains the same if we exclude all municipalities (14 in total) where the structure of party support is not best represented by a linear function of seats in the council.

35 The results are available upon request.
} 
no differences between the different groups. Thus, a more fragmented party structure leads to a sharing rule, which favors small parties both in the left- and right-wing blocs.

Finally, we study if the overallocation of funds differs depending on which specific party is in power. In the sample of municipalities, only three parties have more than 50 percent of the votes: The Centre Party (c); The Conservatives (m) and The Social Democrates (s). We construct three dummies which take the value of one when the specific party $((\mathrm{c}),(\mathrm{m})$ or $(\mathrm{s}))$ has the majority of seats in the council. In the last column, we see that all parties use their dominant positions, although the estimates differ across parties. Specifically, it seems like the Conservative Party is more responsive to the (lack of) competitive pressures than the two other parties.

\section{TABLE 5 HERE}

The result that large parties tend to benefit themselves at the expense of the other parties in the local council is difficult to reconcile with the view that voters' preferences lie behind public party support. This result is also difficult to square with other reasons for why there is a negative relationship between party support and political competition. For example, one possible hypothesis is that parties at the central level strategically spend more of their resources in regions where the share of swing voters is high, i.e. where the degree of competition is high. Such behavior could reduce local parties' demand for local party financing. However, the result showing that the sharing rule depends on the local party structure in a way consistent with local rent extraction suggests that this is not the mechanism at work.

\subsubsection{Electoral cycles in financial support}

As previously mentioned, Ansolabehere et al (2003) find that the degree of both interand intra party competition is strongly related to campaign spending in US gubernatorial elections. A similar pattern in public financial support to parties can be expected if such spending is mainly due to voter demand for information. Further, given that the value of information concerning the political alternatives is especially high in election 
years, we would expect financial party support to be relatively high during those years in municipalities where competition is high.

Our hypothesis is that public party support should be viewed as a rent. Theoretically, political competition affects political rents by making politicians more sensitive to voter demand. If voters display short-sightedness, it is likely that political competition does not only affect the level of political rents, but also the timing of rent extraction. In particular, we expect rent extraction to be relatively low close to elections in regions where political competition is high.

To test these hypotheses, we estimate the following relationship:

$$
\begin{aligned}
\text { Party Support }_{i t}= & \mu_{i}+\zeta \text { Party Support }_{i t-1}+\beta_{1} \text { Election year }_{i t} \\
& +\beta_{2}\left(\text { Political competition }_{i} \times \text { Election year }_{i t}\right)+\gamma \text { Controls }_{i t}+\epsilon_{i t} .
\end{aligned}
$$

In effect, this is a difference-in-difference (DID) specification testing if the difference between regions with high and low competition is different during election years relative to other years. If the interaction coefficient $\beta_{2}$ is negative, this means that the change in rent extraction during election years is relatively low when competition is strong. This would be consistent with the rent-extraction hypothesis, but not with a public interest explanation of public-party financing.

Since we need annual data to perform this exercise, we can only test the relationship among counties. Before turning to the analysis of the effects of political competition on the timing of rent extraction, we investigate if the basic relationship between political competition and rent extraction is also apparent among counties. Even though the number of observations is low, the results reported in the first two columns of Table 6 are surprisingly similar to the results for municipalities presented in Table $3 .{ }^{36}$ Since Swedish counties and municipalities are separate units of political administration, this is a strong robustness check on the basic results for political competition. Thus, political

\footnotetext{
36 Since there is no natural connection between county boundaries and local media markets, we have not included any media variables in the county-level regressions.
} 
competition appears to limit rent extraction in exactly the same way both among counties and municipalities.

\section{TABLE 6 HERE}

Next, we turn to the results from running the above DID-specification with time dummies presented in columns three and four and without time dummies presented in the last two columns. The results show that among counties with strong political competition, the increases in public financial party support are indeed relatively low during election years. The estimates in column four imply that a county with a minimum level of political competition increases party support by almost 2 Swedish kronor during an election year, whereas a county with the maximum level of competition reduces party support by 0.5 Swedish kronor. Once more, the empirical evidence thus supports the rent-extraction hypothesis rather than a public interest story of these transfers. Here, it is important to note that all county-level elections are held on the third Sunday in September. In the late fall after the election, the budget for the post-election year is approved by the newly elected council. For this reason, classifying the election years is straightforward.

One problem with specification (9) is that the lagged dependent variable potentially results in inconsistent estimates due to the dynamic panel data problem. Due to the length of our panel (27 years), the problem is likely to be minor and the results from an Arellano and Bond (1991) type GMM-estimation are close to identical to those in Table 6. As the Arellano-Bond estimator is not particularly well-suited for a long and narrow panel such as ours (Roodman, 2008), we do not present these results but they are available upon request.

\subsubsection{Financial support in left- and right wing municipalities}

Besley and Preston (2007) show both theoretically and empirically that political competition tends to make party-specific policy preferences more moderate. Briefly put, they show that while left-wing governments increase spending more than right-wing 
ones, they do so less when competition is high. The reverse pattern can be observed among right-wing governments. Thus, competition tends to result in policy convergence between the political alternatives.

As can be seen in Tables 3 and 4, the share of left-wing voters in a municipality is positively related to financial support to political parties. This result is consistent with left-wing voters having a relatively strong preference for such support. Therefore, we use the same intuition as Besley and Preston and run separate regressions for municipalities that have been run by left- and right-wing majorities throughout the sample period. ${ }^{37}$ If the level of financial support were determined by party-specific voter preferences, we would expect high competition to reduce such support in left-wing municipalities, but to increase it in right-wing ones. Table 7 shows this not to be the case. Rather, high competition tends to reduce financial support in both left- and right-wing municipalities. That the point estimates are not highly statistically significant is not surprising, since we are now studying a small sample of municipalities with very low initial political competition.

\section{TABLE 7 HERE}

These results go against the view that financial support to political parties is determined by party-specific voter preferences moderated by political competition.

\subsection{Accountability and wages}

So far, the focus has been on the financial party support with which local governments reward the political parties represented in the local council. Now, we turn to another proxy for political rents: politicians' wages. The first column in Table 8 presents the results when estimating the effect of political competition on the wage paid to the

\footnotetext{
37 Municipalities are classified as right- (left-) wing if the parties that constitute the right- (left-) wing bloc have had more than 50 percent of the votes in all elections during the time period.
} 
chairman of the executive board in 1999. The results are in line with the evidence presented earlier and suggest that municipalities with low political competition and low newspaper coverage are associated with higher wages. As shown in column two, the result is not due to endogeneity of political competition. To gauge the size of the effect, suppose that the absolute difference between blocs were to increase by one standard deviation (about 15 percent). Then, wages would increase by 4.6 percent. If newspaper coverage were to increase by one standard deviation, wages would decrease by 2.3 percent. Columns three and four show that also our second measure of political competition cut point density yields similar results.

\section{TABLE 8 HERE}

As for the control variables, there are several reasons to expect a positive effect of income on politicians' wages. One reason is that it is easier to extract rents if there are more resources to extract. Another is that politicians may be rewarded for performance. In this case, they get a higher pay if they act to increase local income, a reason stressed in a study of the determinants of US gubernatorial wages by Di Tella and Fisman (2004). Finally, high income may increase the politicians' reservation wage. This effect should also be picked up by our measure of average house prices in the municipality. However, there is no effect of either of these variables in the first two columns of Table 8. In 1995, income seems to have the predicted positive effect on politicians' wages (columns 3 and 4). As could be expected, a larger population and thus greater responsibility lead to an increase in wages. Interestingly, the share of left-wing votes has no effect on wages. This should be compared to the positive effect of the share of left-wing votes on the level of financial party support.

The next four columns show the results when making use of panel data. When controlling for municipality fixed effects, there are no statistically significant effects of either political competition or media coverage. This result suggests that omitted variables may be driving the results. Alternatively, there is not enough variation within municipalities to identify a significant effect on wages. 


\section{Conclusion}

This paper exploits data on public financial support to political parties and politicians' wages among Swedish local governments to analyze the relation between political accountability and political rent extraction in a non-corrupt democracy. In line with the predictions of political agency models, we find that both increased political competition and increased local media coverage reduce the level of rents. Further, we find that both the structure and the timing of public party financing support the hypothesis that political parties exploit limited political competition to enrich themselves. Thus, this paper presents the first direct evidence of which we are aware, supporting the theoretically long-discussed link between electoral biases that limits political competition and legal political rent extraction.

The results for public financial support indicate that moving from the lowest to the highest within sample degree of political competition would cut public party support by approximately 36 percent. The effect of media coverage is also substantial. These results do not seem to be caused by omitted variables or endogeneity problems, as they are robust to the inclusion of municipality-specific fixed effects and using an instrumental variable approach. Wages are also lower in municipalities where the level of political competition is strong and local newspaper coverage is high. However, it is possible that these results are caused by some omitted variables, as we find no significant effects when using panel data.

A natural extension to this work would be to investigate the effects of limited political competition along other policy dimensions. It might be the case that low competition results in some rent extraction, but that the overall effects are positive, for example by increasing the time horizon of the politicians in power. Previous studies of political competition (Besley and Burgess, 2002; Besley and Case, 2003; Besley et al, 2005) indicate that increased political competition is likely to have positive effects on the quality of policy. Ferraz and Finan (2007), on the other hand, find a positive relation between the quality of public policy and corruption. What is true in the Swedish context is still 
an open question.

Another issue is the relationship between voter information and political competition. In the theoretical and empirical analysis, we have assumed voter information and political competition to be independently determined. Even if there is no correlation between the two variables in our data, it might, however, be the case that they are jointly determined. For example, swing voters may have a greater incentive to become informed about the political alternative. There is definitely scope for further research to study the possible joint determination of these factors.

\section{References}

[1] Acemoglu, Daron (2005) "Constitutions, Politics, and Economics: A Review Essay on Persson and Tabellini's The Economic Effects of Constitutions", Journal of Economic Literature 43:4, 1025-1048.

[2] Adserà, Alicia, Carles Boix, Mark Payne (2003) "Are You Being Served? Political Accountability and the Quality of Government", Journal of Law, Economics, and Organization 19:2, 445-490.

[3] Ahrend, Rudiger (2002) "Press Freedom, Human Capital and Corruption", DELTA Working Papers 2002-11.

[4] Ansolabehere, Stephen, John M de Figueiredo, James M Snyder (2003) "Why is There so Little Money in U.S. Politics?", Journal of Economic Perspectives 17:1 (winter), 105-130.

[5] Arellano, Manuel and Stephen Bond (1991) "Some Tests of Specification for Panel Data: Monte Carlo Evidence and an Application to Employment Equations", Review of Economic Studies 58:2, 277-297.

[6] Besley, Timothy (2004) "Paying Politicians: Theory and Evidence", Joseph Schumpeter Lecture, Journal of the European Economics Association 2:2-3, 193-215. 
[7] Besley, Timothy (2006) Principled Agents? The Political Economy of Good Government, Oxford University Press: Oxford.

[8] Besley, Timothy and Robin Burgess (2002) "The Political Economy of Government and Responsiveness: Theory and Evidence from India", Quarterly Journal of Economics 117:4, 1415-1452.

[9] Besley, Timothy and Anne Case (2003) "Political Institutions and Policy Choices: Evidence from the United States", Journal of Economic Literature 41:1, 7-73.

[10] Besley, Timothy and Andrea Prat (2006) "Handcuffs for the Grabbing Hand? Media Capture and Government Accountability", American Economic Review 96:3, 720-736.

[11] Besley, Timothy and Ian Preston (2007) "Electoral Bias and Policy Choice: Theory and Evidence", Quarterly Journal of Economics 122:4, 1473-1510.

[12] Besley, Timothy, Torsten Persson and Daniel Sturm (2005) "Political Competition and Economic Performance: Theory and Evidence from the United States", NBER Working Paper 11484.

[13] Brunetti, Beatrice and Aymo Weder (2003) "A Free Press is Bad News for Corruption", Journal of Public Economics 87:7-8, 1801-1824

[14] Dahlberg, Matz and Eva Mörk (2006) "Public Employment and the Double Role of Bureaucrats", Public Choice 126:3-4, 387-404.

[15] Di Tella, Rafael and Raymond Fisman (2004) "Are Politicians Really Paid Like Bureaucrats?", Journal of Law and Economics 47:2, 477-514.

[16] Djankov, Simeon, Caralee McLiesh, Tatiana Nenova, Andrei Shleifer (2003) "Who Owns the Media?", Journal of Law and Economics 46:2, 341-381. 
[17] Ferraz, Claudio and Fredrico Finan (2007) "Electoral Accountability and Corruption in Local Governments: Evidence from Audit Reports", IZA Discussion Paper No. 2843.

[18] Gustafsson, Agne (1978) Local Governments in Sweden, Ministry of Local Government, Liber: Stockholm.

[19] Gustafsson, Gunnel (1980) Local Government Reform in Sweden, Liber Läromedel: Lund.

[20] Holmberg, Sören and Henrik Oscarsson (2004) Väljare - Svenskt väljarbeteende under 50 år, Norstedts Juridik: Stockholm.

[21] Johansson, Eva (2003) "Intergovernmental Grants as a Tactical Instrument: Empirical Evidence from Swedish Municipalities", Journal of Public Economics 87: 5-6, 883-915.

[22] Kommunaktuellt (1995), supplement to issue 5, 1995.

[23] Lindbeck, Assar and Jörgen Weibull (1987) "Balanced-Budget Redistribution as the Outcome of Political Competition", Public Choice 52, 273-297.

[24] Mullainathan, Sendhil and Andrei Sheifer (2005) "The Market for News", American Economic Review 95:4, 1031-1053.

[25] Persson, Torsten and Guido Tabellini (2000) Political Economics - Explaining Economic Policy, MIT Press: Cambridge.

[26] Persson, Torsten and Guido Tabellini (2003) The Economic Effects of Constitutions, MIT Press: Cambridge.

[27] Persson, Torsten, Guido Tabellini, Fransesco Trebbi (2003) "Electoral Rules and Corruption", Journal of the European Economic Association 1:4, 958-989.

[28] Pettersson-Lidbom Per (2001) "An Empirical Investigation of the Strategic Use of Debt", Journal of Political Economy 109:3, 570-583. 
[29] Pettersson-Lidbom Per (2008) "Do Parties Matter for Economic Outcomes? A Regression-Discontinuity Approach", Journal of the European Economic Association 6:5, 1037-1056.

[30] Reinikka, Ritva, and Jakob Svensson (2005) "The Power of Information: Evidence from a Newspaper Campaign to Reduce Capture of Public Funds", Working Paper IIES.

[31] Roodman, David (2008) "How to Do xtabond2: An Introduction to "Difference" and "System" GMM in Stata", CGDev Working Paper 103.

[32] SCB (2007) Regionala indelningar i Sverige 2007 (Regional divisions in Sweden 2007), MIS 2007:1.

[33] SOU (1961) Principer för en ny kommunindelning, SOU 1961:9, Stockholm: Beckman.

[34] Svenska Dagbladet 2004-11-30 in article about public party support.

[35] Strömberg, David (1999) "Radio's Impact on New Deal Spending", chapter 2 in The Politics of Public Spending, PhD dissertation at Princeton University.

[36] Strömberg, David (2004) "Radio's Impact on Public Spending", Quarterly Journal of Economics 119:1, 189-221.

[37] Svensson. Jakob (2005) "Eight Questions about Corruption", Journal of Economic Perspectives 19:3, 19-42.

[38] Waisman, Gisela (2006) "Complementary Controls of Corruption", chapter 4 in Essays on Discrimination and Corruption, $\mathrm{PhD}$ dissertaion at IIES Stockholm University.

[39] Wittman, Donald (1989) "Why Democracies Produce Efficient Results, Journal of Political Economy 97:6, 1395-1424. 


\section{Data appendix}

The main units of observation are Swedish municipalities. All municipalities have an official code reported in the publication SCB (2007). Out of a total of 290 municipalities (in 2003), we drop municipalities for the following reasons.

Municipalities that have split or merged since 1974:

Codes: 117 (Österåker), 127 (Botkyrka), 128 (Salem), 140 (Nykvarn), 181 (Södertälje), 187 (Vaxholm), 330 (Knivsta), 461 (Gnesta), 480 (Nyköping), 488 (Trosa), 583 (Motala), 584 (Vadstena), 1229 (Bara), 1263 (Svedala), 1443 (Bollebygd), 1445 (Essunga), 1470 (Vara), 1490 (Borås), 1814 (Lekeberg), 1880 (Örebro), 2403 (Bjurholm), 2417 (Norsjö), 2425 (Dorotea), 2460 (Vännäs), 2463 (Åsele)

Municipalities dropped in the post-1995 period due to misreported values of public party support.

Codes: 120 (Värmdö), 123 (Järfälla), 183 (Sundbyberg), 509 (Ödeshög), 1419 (Tjörn), 2184 (Hudiksvall), 2401 (Nordmaling), 2404 (Vindeln), 2409 (Robertsfors), 2521 (Pajala), 2584 (Kiruna)

Municipalities dropped in the pre-1995 period due to misreported values of public party support:

Codes: 2401 (Nordmaling), 2409 (Robertsfors), 2584 (Kiruna)

Municipalities dropped in the cross-sectional studies due to missing data for the instrument polcomp68:

Code: 481 (Oxelösund), 1885 (Lindesberg), 2418 (Malå)

Municipalities dropped in the panel studies due to missing data for the instrument blocdiff: Code: 980 (Gotland). 
Table A1. Data description and sources

\begin{tabular}{|c|c|c|}
\hline Variable & Description & Source \\
\hline Party support & $\begin{array}{l}\text { Public financial party support per capita (post election years } \\
1974,1977,1980,1983,1986,1989,1992,1995,1999,2003) .\end{array}$ & $\begin{array}{l}\text { SALAR(1) for } \\
\text { 1974-1995. SKL } \\
\text { 1999-2003. }\end{array}$ \\
\hline Wage & $\begin{array}{l}\text { Monthly salary paid to the highest ranking full-time employed } \\
\text { politician (post election years } 1974,1977,1980,1983,1986, \\
\text { 1989, 1992, 1995, 1999). Thousands of Swedish kronor. }\end{array}$ & $\begin{array}{l}\text { SALAR(1) 1974- } \\
1989, \text { KA 1990- } \\
1999 .\end{array}$ \\
\hline Base/seat & $\begin{array}{l}\text { The ratio between base (per party) public party support and per } \\
\text { seat public party support. }\end{array}$ & OWN \\
\hline $\begin{array}{l}\text { Political } \\
\text { competition }\end{array}$ & $\begin{array}{l}\text { One minus the absolute difference between the vote share of the } \\
\text { left-wing (Social Democrats, the Left Party (former } \\
\text { Communists), the Green Party) and the right-wing (the } \\
\text { Conservatives, the Liberals, the Centre Party, the Christian } \\
\text { Democrats, and New Democracy) parties. We use both the } \\
\text { average over 1974-2003 and for individual years, depending on } \\
\text { the specification. }\end{array}$ & SS \\
\hline $\begin{array}{l}\text { Cutpoint } \\
\text { density }\end{array}$ & $\begin{array}{l}\text { Cutpoint density measure of swing voters (years } 1992 \text { and } \\
\text { 1995). See text for definition. }\end{array}$ & EJ (2003) \\
\hline Polcomp68 & $\begin{array}{l}\text { Absolute difference between the vote share of the left-wing and } \\
\text { the right-wing parties in the } 1968 \text { national election. }\end{array}$ & SSD \\
\hline Blocdiff & $\begin{array}{l}\text { The average difference between the vote share of the left-wing } \\
\text { (right-wing) and the right-wing (left-wing) parties in bordering } \\
\text { municipalities for municipalities governed by a left-wing (right- } \\
\text { wing) majority }\end{array}$ & SS \\
\hline Coverage & $\begin{array}{l}\text { Sum of household coverage of local newspapers (percent of } \\
\text { households that read a particular paper) that have a coverage of } \\
\text { at least } 10 \text { percent and are published at least twice a week. }\end{array}$ & TS \\
\hline Income & Taxable income per capita. & SS \\
\hline Population & Population size. & SS \\
\hline Pop density & Population density. & SS \\
\hline Public exp & $\begin{array}{l}\text { Total public expenditure as a share of total municipal taxable } \\
\text { income. }\end{array}$ & SALAR(2) \\
\hline Tax rate & Municipal tax rate. & SS \\
\hline High edu & $\begin{array}{l}\text { The share of the population with at least some post-secondary } \\
\text { education (available from 1985). }\end{array}$ & SS \\
\hline Leftwing & Vote share of left-wing parties & SS \\
\hline Seats & Number of seats in the municipal assembly. & SS \\
\hline Herfindahl & Herfindahl index of parties in the local assembly. & SS \\
\hline Own majority & $\begin{array}{l}\text { Dummy taking the value of one if a single party holds more } \\
\text { than } 50 \% \text { of the seats in the municipal assembly. }\end{array}$ & SS \\
\hline Parties & Number of parties in municipal assembly. & SS \\
\hline Age $0-15$ & Share of population aged $0-15$. & SS \\
\hline Age $65+$ & Share of population aged 65 and above. & SS \\
\hline Woman & $\begin{array}{l}\text { Dummy that takes the value of } 1 \text { if the chairman of the } \\
\text { executive committee is a woman. }\end{array}$ & KA \\
\hline Age & Age of the chairman of the executive committee. & KA \\
\hline House prices & Average price of a free-standing house in the municipality & SS \\
\hline
\end{tabular}

SALAR is the Swedish Association of Local Authorities and Regions: (1) "Kommunalt förtroendevalda och deras arvoden” (1974-2000), (2) “Årsboken för Sveriges kommuner” (1976-2006); SS is Statistics Sweden, downloaded from "Statistikdatabasen" http://www.ssd.scb.se/; SKL is downloaded from www.webor.se; SSD is Svensk Samhällsvetenskaplig Datatjänst, dataset number 0148; KA is KommunAktuellt (various issues 19802000); TS is Tidningsstatistik AB, "TS-boken" (1974-2003); OWN is from a survey conducted by the authors in June-September 2006. For more information about how the data is coded see under Table A3; EJ (2003) is Johansson (2003). 
Table A2. List of the 10 municipalities with the lowest and highest level of party support per capita 2003.

\begin{tabular}{|c|c|c|c|c|}
\hline Municipality & $\begin{array}{l}\text { Party support } \\
\text { per capita }\end{array}$ & $\begin{array}{c}\text { Base support } \\
\text { per party }\end{array}$ & $\begin{array}{c}\text { Support per } \\
\text { seat }\end{array}$ & Population \\
\hline \multicolumn{5}{|c|}{ Municipalities with the lowest level of party support per capita } \\
\hline Söderköping & 8 & 1500 & 1422 & 14009 \\
\hline Torsås & 12 & 2196 & 2125 & 7293 \\
\hline Kil & 13 & 7000 & 3000 & 11892 \\
\hline Munkedal & 14 & 3500 & 3500 & 10434 \\
\hline Bengtsfors & 15 & 2550 & 1785 & 10516 \\
\hline Kungälv & 15 & 11400 & 8300 & 37912 \\
\hline Vårgårda & 15 & 3000 & 3100 & 10668 \\
\hline Valdemarsvik & 16 & 5000 & 2400 & 8230 \\
\hline Vellinge & 16 & 0 & 9650 & 31087 \\
\hline Svenljunga & 16 & 1000 & 4025 & 10529 \\
\hline \multicolumn{5}{|c|}{ Municipalities with the highest level of party support per capita } \\
\hline Övertorneå & 78 & 19300 & 7720 & 5391 \\
\hline Vilhelmina & 85 & 50000 & 10000 & 7655 \\
\hline Jokkmokk & 85 & 10000 & 11500 & 5782 \\
\hline Gotland & 86 & & 47033 & 57381 \\
\hline Ockelbo & 87 & & & 6101 \\
\hline Timrå & 87 & 14957 & 29122 & 17784 \\
\hline Arvidsjaur & 88 & 15000 & 17055 & 7017 \\
\hline Boden & 92 & 79590 & 29215 & 28268 \\
\hline Arjeplog & 117 & 0 & 12419 & 3291 \\
\hline Haparanda & 121 & 38600 & 19300 & 10334 \\
\hline
\end{tabular}

Note: 207 out of 290 did answer our survey on the structure of party support. Therefore, data on Base support per party and Support per seat is missing for some municipalities. All values in fixed (2000) SEK. 
Table 1 . Summary statistics

\begin{tabular}{|c|c|c|c|c|c|c|}
\hline variable & $\mathrm{N}$ & mean & median & $\mathrm{sd}$ & $\min$ & $\max$ \\
\hline \multicolumn{7}{|c|}{ Municipalities } \\
\hline Party support & 2537 & 31.73 & 29.04 & 14.44 & 4.35 & 115.23 \\
\hline Wage 1000 SEK & 1748 & 27.83 & 27.48 & 5.812 & 13.81 & 71.22 \\
\hline Base/seats & 207 & 1.39 & 1 & 1.49 & 0 & 15.31 \\
\hline Political competition & 2537 & 0.81 & 0.84 & 0.14 & 0.27 & 1 \\
\hline Cutpoint density & 492 & 0.03 & 9.03 & 0.01 & 0.01 & 0.05 \\
\hline Herfindahl & 254 & 0.25 & 0.83 & 0.05 & 0.18 & 0.48 \\
\hline Own majority & 254 & 0.13 & 0.27 & 0.34 & 0 & 1 \\
\hline Polcomp68 & 2510 & 0.20 & 0 & 0.15 & 0.00 & 0.64 \\
\hline Blocdiff & 2518 & 0.07 & 0.09 & 0.16 & -0.39 & 0.58 \\
\hline Coverage & 2524 & 86.14 & 86.00 & 19.77 & 19.07 & 178 \\
\hline Income 1000 SEK & 2537 & 90.95 & 0.88 & 19.73 & 41.590 & 245.78 \\
\hline Population & 2537 & 30221.50 & 16010 & 56016.85 & 3046 & 758148 \\
\hline Pop density & 2537 & 106.52 & 26.41 & 339.25 & 0.25 & 4047.99 \\
\hline High edu & 1523 & 0.11 & 0.10 & 0.05 & 0.04 & 0.43 \\
\hline Leftwing & 2537 & 0.50 & 0.50 & 0.12 & 0.13 & 0.83 \\
\hline Seats & 254 & 46.30 & 45 & 11.65 & 31 & 101 \\
\hline Parties & 254 & 7.14 & 7 & 0.83 & 5 & 8 \\
\hline Woman & 2022 & 0.12 & 0 & 0.32 & 0 & 1 \\
\hline Age & 1771 & 50.81 & 51 & 7.74 & 25 & 71 \\
\hline House prices 1000 SEK & 2530 & 668.012 & 585.16 & 338.82 & 163.53 & 3908.60 \\
\hline \multicolumn{7}{|c|}{ Counties } \\
\hline Party support & 606 & 19.54 & 18.87 & 4.94 & 8.82 & 37.47 \\
\hline Political competition & 611 & 0.87 & 0.87 & 0.09 & 0.59 & 0.99 \\
\hline Income $1000 \mathrm{SEK}$ & 629 & 95.91 & 94.38 & 15.52 & 73.78 & 160.56 \\
\hline Population & 629 & 353793.70 & 272539 & 319136.50 & 127645 & 1860872 \\
\hline Public exp & 627 & 17.52 & 17.29 & 2.55 & 12.22 & 29.12 \\
\hline Leftwing & 611 & 0.53 & 0.53 & 0.07 & 0.38 & 0.69 \\
\hline
\end{tabular}

For municipalities, see Table A1 for sources and definitions. For counties, the following sources are used: Party support and Public exp are from Svenska kommunförbundet "Statistisk årsbok för landsting” (1976-2005);

Political competition, Income, Population, and Leftwing are from Statistics Sweden "Statistikdatabasen" http://www.ssd.scb.se/. All monetary values are in fixed (2000) Swedish kronor (SEK). 


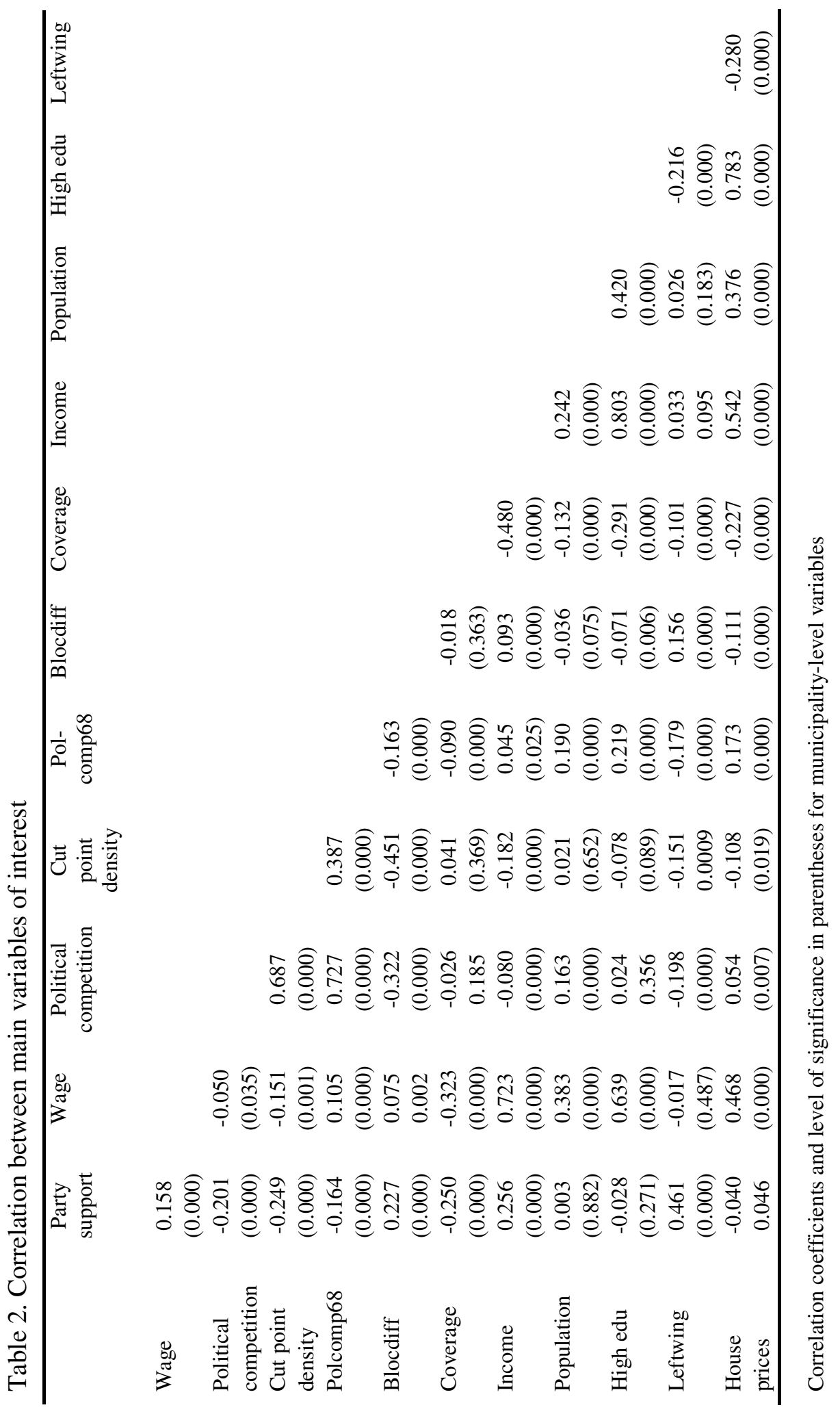


Table 3. Main results for political competition

\begin{tabular}{|c|c|c|c|c|c|c|c|c|}
\hline & \multicolumn{8}{|c|}{ Public financial support to political parties (per capita) } \\
\hline & $\begin{array}{l}\text { OLS } \\
2003 \\
\end{array}$ & $\begin{array}{c}\text { IV } \\
2003 \\
\end{array}$ & $\begin{array}{l}\text { OLS } \\
1995\end{array}$ & $\begin{array}{c}\text { IV } \\
1995 \\
\end{array}$ & $\begin{array}{c}\text { OLS-FE } \\
1974-2003 \\
\end{array}$ & $\begin{array}{l}\text { IV-FE } \\
1974-2003 \\
\end{array}$ & $\begin{array}{c}\text { OLS-FE } \\
1992-1995\end{array}$ & $\begin{array}{c}\text { OLS-IV } \\
1992-1995\end{array}$ \\
\hline $\begin{array}{l}\text { Political } \\
\text { competition }\end{array}$ & $\begin{array}{c}-15.92 * * \\
(7.30)\end{array}$ & $\begin{array}{l}-21.51 * \\
(12.55)\end{array}$ & & & $\begin{array}{l}-3.04 \\
(2.82)\end{array}$ & $\begin{array}{c}-26.26 * * \\
(12.91)\end{array}$ & & \\
\hline $\begin{array}{l}\text { Cut point } \\
\text { density }\end{array}$ & & & $\begin{array}{c}-520.78 * * * \\
(152.19)\end{array}$ & $\begin{array}{c}-842.81 * * \\
(361.76)\end{array}$ & & & $\begin{array}{c}-133.40 * * * \\
(48.07)\end{array}$ & $\begin{array}{c}-177.83 * \\
(104.36)\end{array}$ \\
\hline Income & $\begin{array}{c}13.59 \\
(13.08)\end{array}$ & $\begin{array}{c}10.03 \\
(15.00)\end{array}$ & $\begin{array}{c}32.04 * * * \\
(10.70)\end{array}$ & $\begin{array}{c}28.18 * * \\
(11.06)\end{array}$ & $\begin{array}{l}-9.98 \\
(8.58)\end{array}$ & $\begin{array}{l}-9.40 \\
(8.44)\end{array}$ & $\begin{array}{c}-6.09 \\
(28.05)\end{array}$ & $\begin{array}{c}-2.00 \\
(28.29)\end{array}$ \\
\hline Population & $\begin{array}{c}-0.13 \\
(1.99)\end{array}$ & $\begin{array}{c}0.24 \\
(2.00)\end{array}$ & $\begin{array}{l}-0.79 \\
(1.55)\end{array}$ & $\begin{array}{l}-0.11 \\
(1.57)\end{array}$ & $\begin{array}{c}-12.33^{* * * *} \\
(4.60)\end{array}$ & $\begin{array}{c}-9.91 * * \\
(4.78)\end{array}$ & $\begin{array}{c}-4.29 \\
(26.67)\end{array}$ & $\begin{array}{c}1.77 \\
(31.12)\end{array}$ \\
\hline Leftwing & $\begin{array}{c}54.69 * * * \\
(8.34)\end{array}$ & $\begin{array}{c}53.15 * * * \\
(8.92)\end{array}$ & $\begin{array}{c}47.57 * * * \\
(8.32)\end{array}$ & $\begin{array}{c}37.47 * * * \\
(12.52)\end{array}$ & $\begin{array}{c}6.78 \\
(7.19)\end{array}$ & $\begin{array}{c}4.55 \\
(8.50)\end{array}$ & $\begin{array}{c}-2.95 \\
(15.46)\end{array}$ & $\begin{array}{c}-4.13 \\
(16.21)\end{array}$ \\
\hline High edu. & $\begin{array}{l}-16.61 \\
(30.68)\end{array}$ & $\begin{array}{l}-15.47 \\
(30.72)\end{array}$ & $\begin{array}{l}-37.91 \\
(30.77)\end{array}$ & $\begin{array}{l}-41.41 \\
(31.47)\end{array}$ & & & $\begin{array}{c}43.87 \\
(110.24)\end{array}$ & $\begin{array}{c}41.48 \\
(111.76)\end{array}$ \\
\hline Mun effects & & & & & Yes & Yes & Yes & Yes \\
\hline Time effects & & & & & Yes & Yes & Yes & Yes \\
\hline F-test & & 101.18 & & 31.15 & & 320.52 & & 68.95 \\
\hline Observations & 251 & 251 & 244 & 244 & 2528 & 2528 & 492 & 492 \\
\hline R-squared & 0.19 & & 0.36 & & 0.75 & & 0.94 & \\
\hline
\end{tabular}

The dependent variable is public party support per capita. F-test reports the F-statistics on the instrument from the first-stage regression. The instrument for political competition and cut point density is polcomp68 in columns (2) and (4) and blockdiff in columns (6) and (8). Robust standard errors reported in parentheses. In columns (5) and (6) standard errors are clustered at the municipality level. *** $\mathrm{p}<0.01, * * \mathrm{p}<0.05, * \mathrm{p}<0.1$. Constant not presented. 
Table 4. Adding media and effects of shocks

\begin{tabular}{|c|c|c|c|c|c|c|}
\hline & (1) & (2) & (3) & (4) & (5) & (6) \\
\hline & \multicolumn{6}{|c|}{ Public financial support to political parties (per capita) } \\
\hline & OLS & IV & OLS-FE & IV-FE & OLS-FE & IV-FE \\
\hline & 2003 & 2003 & 1974-2003 & 1974-2003 & 1974-2003 & 1974-2003 \\
\hline \multirow[t]{2}{*}{ Coverage } & $-0.13 *$ & $-0.14 *$ & $-0.08 * *$ & $-0.10 * *$ & $-0.08 * *$ & $-0.09 * *$ \\
\hline & $(0.07)$ & $(0.07)$ & $(0.04)$ & $(0.04)$ & $(0.04)$ & $(0.04)$ \\
\hline \multirow{4}{*}{$\begin{array}{l}\text { Political } \\
\text { competition } \\
\text { Polcomp } \times \\
\text { income }\end{array}$} & $-18.66 * * *$ & $-26.54 * *$ & -3.68 & $-28.32 * *$ & -4.51 & $-28.20 * *$ \\
\hline & (7.08) & (12.69) & $(2.83)$ & (13.16) & (2.99) & $(13.42)$ \\
\hline & & & & & -10.35 & $-60.40 *$ \\
\hline & & & & & (10.04) & $(33.53)$ \\
\hline \multirow[t]{2}{*}{ Income } & 5.98 & 1.90 & -8.52 & -7.69 & -1.13 & 35.29 \\
\hline & (13.82) & (15.97) & (8.61) & $(8.46)$ & $(10.75)$ & $(24.87)$ \\
\hline \multirow[t]{2}{*}{ Population } & -0.18 & 0.28 & $-14.31 * * *$ & $-12.00 * *$ & $-13.81 * * *$ & $-9.55^{*}$ \\
\hline & $(1.95)$ & $(2.01)$ & $(4.50)$ & $(4.68)$ & $(4.50)$ & $(5.15)$ \\
\hline \multirow[t]{2}{*}{ Leftwing } & $53.05 * * *$ & $51.87 * * *$ & 4.98 & 2.15 & 5.13 & 3.57 \\
\hline & $(8.23)$ & (9.09) & (7.14) & (8.63) & (7.22) & (9.33) \\
\hline \multirow[t]{2}{*}{ High edu. } & -9.80 & -9.64 & & & & \\
\hline & (30.83) & (30.89) & & & & \\
\hline Mun effects & & & Yes & Yes & Yes & Yes \\
\hline Time effects & & & Yes & Yes & Yes & Yes \\
\hline F-test & & 91.75 & & 313.23 & & 157.43 \\
\hline F-test (interact) & & & & & & 165.51 \\
\hline Observations & 254 & 251 & 2515 & 2515 & 2515 & 2515 \\
\hline R-squared & 0.20 & & 0.75 & & 0.75 & \\
\hline
\end{tabular}

The dependent variable is public party support per capita. F-test reports the F-statistics on the instrument from the first-stage regression (both the direct effect and for the interaction term, where applicable). The instrument for political competition is polcomp68 in column (2) and blockdiff in columns (4) and (6). Robust standard errors reported in parentheses. In columns (3) - (6) standard errors are clustered at the municipality level. $* * * p<0.01$, $* * \mathrm{p}<0.05, * \mathrm{p}<0.1$. Constant not presented. 
Table 5. The structure of party support

\begin{tabular}{|c|c|c|c|c|c|}
\hline & \multicolumn{5}{|c|}{ Base/mandate } \\
\hline & $\begin{array}{l}\text { OLS } \\
2003\end{array}$ & $\begin{array}{l}\text { OLS } \\
2003\end{array}$ & $\begin{array}{l}\text { OLS } \\
2003\end{array}$ & $\begin{array}{l}\text { OLS } \\
2003\end{array}$ & $\begin{array}{l}\text { OLS } \\
2003\end{array}$ \\
\hline Herfindahl & $\begin{array}{c}-5.60 * * * \\
(2.02)\end{array}$ & & $\begin{array}{c}-6.26 * * \\
(2.54)\end{array}$ & & \\
\hline Own majority & & $\begin{array}{c}-0.46 * * * \\
(0.17)\end{array}$ & & & \\
\hline Herfindahl $\times$ left & & & $\begin{array}{c}0.57 \\
(1.07)\end{array}$ & & \\
\hline Herfindahl $\times$ right & & & $\begin{array}{c}1.14 \\
(1.34)\end{array}$ & & \\
\hline Herf. in left majority & & & & $\begin{array}{c}-3.65^{* *} \\
(1.63)\end{array}$ & \\
\hline Herf. in right majority & & & & $\begin{array}{c}-3.78 * * \\
(1.85)\end{array}$ & \\
\hline $\begin{array}{l}\text { Herf when no left/right } \\
\text { majority }\end{array}$ & & & & $\begin{array}{l}-3.02 \\
(1.84)\end{array}$ & \\
\hline C own majority & & & & & $\begin{array}{c}-0.65 * * * \\
(0.12)\end{array}$ \\
\hline M own majority & & & & & $\begin{array}{c}-1.44 * * * \\
(0.12)\end{array}$ \\
\hline S own majority & & & & & $\begin{array}{c}-0.41 * * \\
(0.17)\end{array}$ \\
\hline Observations & 207 & 207 & 207 & 207 & 207 \\
\hline R-squared & 0.03 & 0.01 & 0.03 & 0.03 & 0.01 \\
\hline
\end{tabular}

The dependent variable is the financial party support (base) divided with the per seat financial support (seat). Robust standard errors reported in parentheses. $* * * \mathrm{p}<0.01, * * \mathrm{p}<0.05, * \mathrm{p}<0.1$. Constant not presented. 
Table 6. Election cycles in party support (county level)

\begin{tabular}{|c|c|c|c|c|c|c|}
\hline & \multicolumn{6}{|c|}{ Public financial support to political parties (per capita) } \\
\hline & OLS & IV & OLS & IV & OLS-FE & IV-FE \\
\hline & 2003 & 2003 & $1977-2003$ & $1977-2003$ & $1977-2003$ & $1977-2003$ \\
\hline \multirow{6}{*}{$\begin{array}{l}\text { Political } \\
\text { competition } \\
\text { Election yearx } \\
\text { pol comp } \\
\text { Election year }\end{array}$} & -17.88 & $-47.53 *$ & 0.37 & -0.24 & 1.13 & 1.47 \\
\hline & $(12.50)$ & $(25.17)$ & $(1.06)$ & $(2.01)$ & $(1.42)$ & $(1.80)$ \\
\hline & & & $-5.80 * * *$ & $-6.88 * *$ & $-5.43 * * *$ & -5.35 \\
\hline & & & $(1.82)$ & $(3.05)$ & $(1.83)$ & $(3.33)$ \\
\hline & & & $5.26 * * *$ & $6.20 * *$ & & \\
\hline & & & $(1.54)$ & $(2.66)$ & & \\
\hline \multirow[t]{2}{*}{ Income } & -8.82 & $-21.36^{*}$ & $2.84 * *$ & $2.71 * * *$ & 3.64 & 3.49 \\
\hline & (12.79) & (11.95) & $(1.07)$ & $(0.97)$ & $(7.05)$ & $(6.84)$ \\
\hline \multirow[t]{2}{*}{ Population } & -1.57 & -1.09 & $-6.34 * *$ & $-5.96 * *$ & $-10.23 * *$ & $-10.45 * * *$ \\
\hline & $(1.76)$ & $(1.75)$ & (2.69) & $(2.72)$ & (3.77) & (3.62) \\
\hline \multirow[t]{2}{*}{ Leftwing } & $33.79 * *$ & -4.24 & 0.86 & 0.42 & -6.22 & $-6.26^{*}$ \\
\hline & $(14.00)$ & $(44.41)$ & $(2.15)$ & (2.69) & $(3.85)$ & $(3.72)$ \\
\hline \multirow[t]{2}{*}{ Party support ${ }_{\mathrm{t}-1}$} & & & $0.74 * * *$ & $0.74 * * *$ & $0.70 * * *$ & $0.70 * * *$ \\
\hline & & & $(0.04)$ & $(0.04)$ & $(0.06)$ & $(0.06)$ \\
\hline County effects & & & Yes & Yes & Yes & Yes \\
\hline Time effects & & & & & Yes & Yes \\
\hline F-test & & 11.87 & & 177.35 & & 112.18 \\
\hline F-test (interact) & & & & 118.17 & & 77.16 \\
\hline Observations & 20 & 20 & 573 & 573 & 573 & 573 \\
\hline R-squared & 0.64 & & 0.88 & & 0.89 & \\
\hline
\end{tabular}

The dependent variable is public party support per capita. F-test reports the F-statistics on the instrument from the first-stage regression (both the direct effect and for the interaction term, where applicable). The instrument for political competition and is polcomp60 in column (2) and blockdiff in columns (4) and (6). Robust standard errors reported in parentheses. In columns (3)-(6) standard errors are clustered at the county level. $* * * \mathrm{p}<0.01$, $* * \mathrm{p}<0.05, * \mathrm{p}<0.1$. Constant not presented. 
Table 7. Right-wing and left-wing municipalities

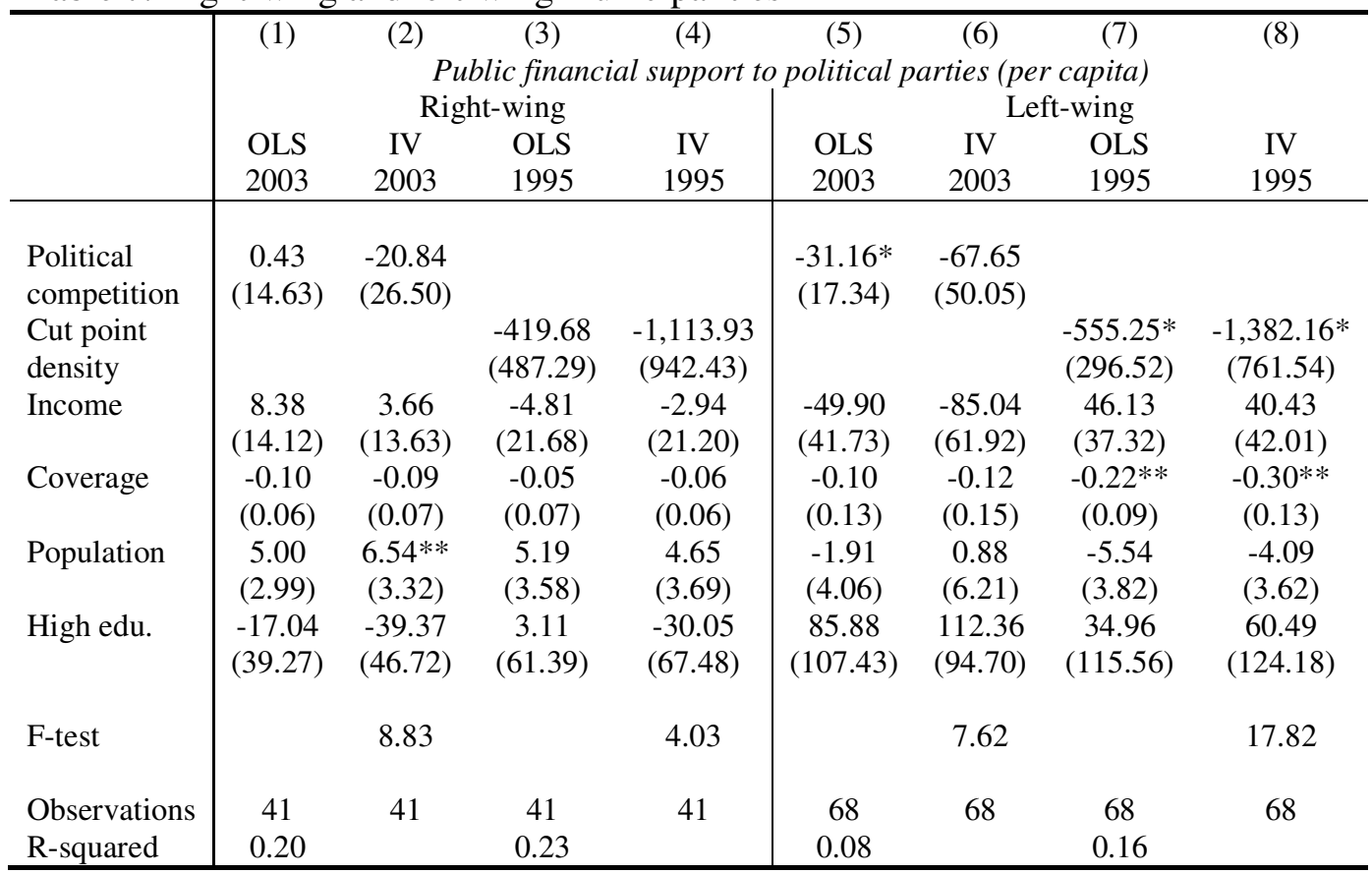

The dependent variable is public party support per capita. In the sample of municipalities used in (1) - (4), the right-wing bloc has had more than 50 percent of the votes in all elections 1974-2003. Equivalent but left-wing in (5) - (8). F-test reports the F-statistics on the instrument from the first-stage regression. The instrument for political competition is polcomp68. Robust standard errors reported in parentheses. $* * * \mathrm{p}<0.01$, ** $\mathrm{p}<0.05$, * $\mathrm{p}<0.1$. Constant not presented. 
Table 8. Wages

\begin{tabular}{|c|c|c|c|c|c|c|c|c|}
\hline \multirow{4}{*}{ 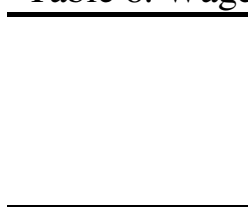 } & (1) & (2) & (3) & (4) & $(5)$ & (6) & (7) & (8) \\
\hline & \multicolumn{8}{|c|}{ Wage of highest paid politician (ln) } \\
\hline & OLS & IV & OLS & IV & OLS-FE & IV-FE & OLS-FE & IV-FE \\
\hline & 1999 & 1999 & 1995 & 1995 & $\begin{array}{c}1974- \\
1999\end{array}$ & $\begin{array}{c}1974- \\
1999\end{array}$ & $\begin{array}{c}1992- \\
1995\end{array}$ & $\begin{array}{l}1992- \\
1995\end{array}$ \\
\hline $\begin{array}{l}\text { Political } \\
\text { competition }\end{array}$ & $\begin{array}{c}-0.31 * * * \\
(0.09)\end{array}$ & $\begin{array}{c}-0.21 * * \\
(0.11)\end{array}$ & & & $\begin{array}{l}-0.03 \\
(0.04)\end{array}$ & $\begin{array}{c}0.04 \\
(0.13)\end{array}$ & & \\
\hline $\begin{array}{l}\text { Cut point } \\
\text { density }\end{array}$ & & & $\begin{array}{c}-2.73 * * \\
(1.26)\end{array}$ & $\begin{array}{l}-5.34 * \\
(2.83)\end{array}$ & & & $\begin{array}{l}-0.60 \\
(1.03)\end{array}$ & $\begin{array}{l}1.90 \\
(2.79)\end{array}$ \\
\hline Coverage/1000 & $\begin{array}{c}-1.42 * * * \\
(0.50)\end{array}$ & $\begin{array}{c}-1.30 * * \\
(0.52)\end{array}$ & $\begin{array}{l}-0.41 \\
(0.39)\end{array}$ & $\begin{array}{l}-0.46 \\
(0.39)\end{array}$ & $\begin{array}{c}0.00 \\
(0.33)\end{array}$ & $\begin{array}{c}0.04 \\
(0.32)\end{array}$ & $\begin{array}{l}0.15 \\
(0.55)\end{array}$ & $\begin{array}{c}0.10 \\
(0.60)\end{array}$ \\
\hline Woman & $\begin{array}{l}-0.02 \\
(0.02)\end{array}$ & $\begin{array}{l}-0.02 \\
(0.02)\end{array}$ & $\begin{array}{l}-0.02 \\
(0.02)\end{array}$ & $\begin{array}{l}-0.02 \\
(0.02)\end{array}$ & & & & \\
\hline Age & $\begin{array}{c}0.01 \\
(0.01)\end{array}$ & $\begin{array}{c}0.01 \\
(0.01)\end{array}$ & $\begin{array}{c}0.01 \\
(0.01)\end{array}$ & $\begin{array}{c}0.01 \\
(0.01)\end{array}$ & & & & \\
\hline $\operatorname{Age}^{2}$ & $\begin{array}{l}-0.00 \\
(0.00)\end{array}$ & $\begin{array}{l}-0.00 \\
(0.00)\end{array}$ & $\begin{array}{l}-0.00 \\
(0.00)\end{array}$ & $\begin{array}{l}-0.00 \\
(0.00)\end{array}$ & & & & \\
\hline House prices & $\begin{array}{l}0.06 \\
(0.04)\end{array}$ & $\begin{array}{c}0.04 \\
(0.04)\end{array}$ & $\begin{array}{l}-0.02 \\
(0.04)\end{array}$ & $\begin{array}{l}-0.00 \\
(0.05)\end{array}$ & $\begin{array}{c}0.02 \\
(0.04)\end{array}$ & $\begin{array}{c}0.02 \\
(0.04)\end{array}$ & $\begin{array}{c}0.04 \\
(0.08)\end{array}$ & $\begin{array}{c}0.06 \\
(0.09)\end{array}$ \\
\hline Income & $\begin{array}{c}0.07 \\
(0.13)\end{array}$ & $\begin{array}{c}0.15 \\
(0.15)\end{array}$ & $\begin{array}{c}0.47 * * * \\
(0.11)\end{array}$ & $\begin{array}{c}0.40^{* * * *} \\
(0.13)\end{array}$ & $\begin{array}{c}0.15 \\
(0.12)\end{array}$ & $\begin{array}{c}0.15 \\
(0.12)\end{array}$ & $\begin{array}{l}-0.22 \\
(0.46)\end{array}$ & $\begin{array}{l}-0.49 \\
(0.53)\end{array}$ \\
\hline Population & $\begin{array}{c}0.10 * * * \\
(0.02)\end{array}$ & $\begin{array}{c}0.09 * * * \\
(0.02)\end{array}$ & $\begin{array}{c}0.08 * * * \\
(0.01)\end{array}$ & $\begin{array}{c}0.09 * * * \\
(0.01)\end{array}$ & $\begin{array}{c}0.04 \\
(0.09)\end{array}$ & $\begin{array}{c}0.04 \\
(0.09)\end{array}$ & $\begin{array}{c}0.06 \\
(0.41)\end{array}$ & $\begin{array}{l}-0.25 \\
(0.42)\end{array}$ \\
\hline Leftwing & $\begin{array}{l}-0.05 \\
(0.09)\end{array}$ & $\begin{array}{l}-0.02 \\
(0.08)\end{array}$ & $\begin{array}{l}-0.08 \\
(0.08)\end{array}$ & $\begin{array}{l}-0.14 \\
(0.10)\end{array}$ & $\begin{array}{l}-0.11 \\
(0.11)\end{array}$ & $\begin{array}{l}-0.10 \\
(0.11)\end{array}$ & $\begin{array}{c}0.01 \\
(0.21)\end{array}$ & $\begin{array}{c}0.05 \\
(0.21)\end{array}$ \\
\hline High edu & $\begin{array}{c}0.37 \\
(0.36)\end{array}$ & $\begin{array}{c}0.38 \\
(0.36)\end{array}$ & $\begin{array}{c}0.20 \\
(0.29)\end{array}$ & $\begin{array}{c}0.14 \\
(0.29)\end{array}$ & & & & \\
\hline Mun effects & & & & & Yes & Yes & Yes & Yes \\
\hline Time effects & & & & & Yes & Yes & Yes & Yes \\
\hline F-test & & 98.68 & & 36.29 & & 261.24 & & 73.06 \\
\hline Observations & 254 & 254 & 245 & 245 & 2179 & 2179 & 490 & 490 \\
\hline R-squared & 0.54 & & 0.58 & & 0.77 & & 0.90 & \\
\hline
\end{tabular}

The dependent variable is the wage of the highest paid politician. F-test reports the F-statistics on the instrument from the first-stage regression. The instrument for political competition and cut point density is polcomp68 in columns (2) and (4) and blockdiff in columns (6) and (8). Robust standard errors reported in parentheses. In columns (5) - (8) standard errors are clustered at the municipality level. *** $\mathrm{p}<0.01,{ }^{* *} \mathrm{p}<0.05,{ }^{*} \mathrm{p}<0.1$.

Constant not presented. 
Figure 1. The evolution of municipal-level party support

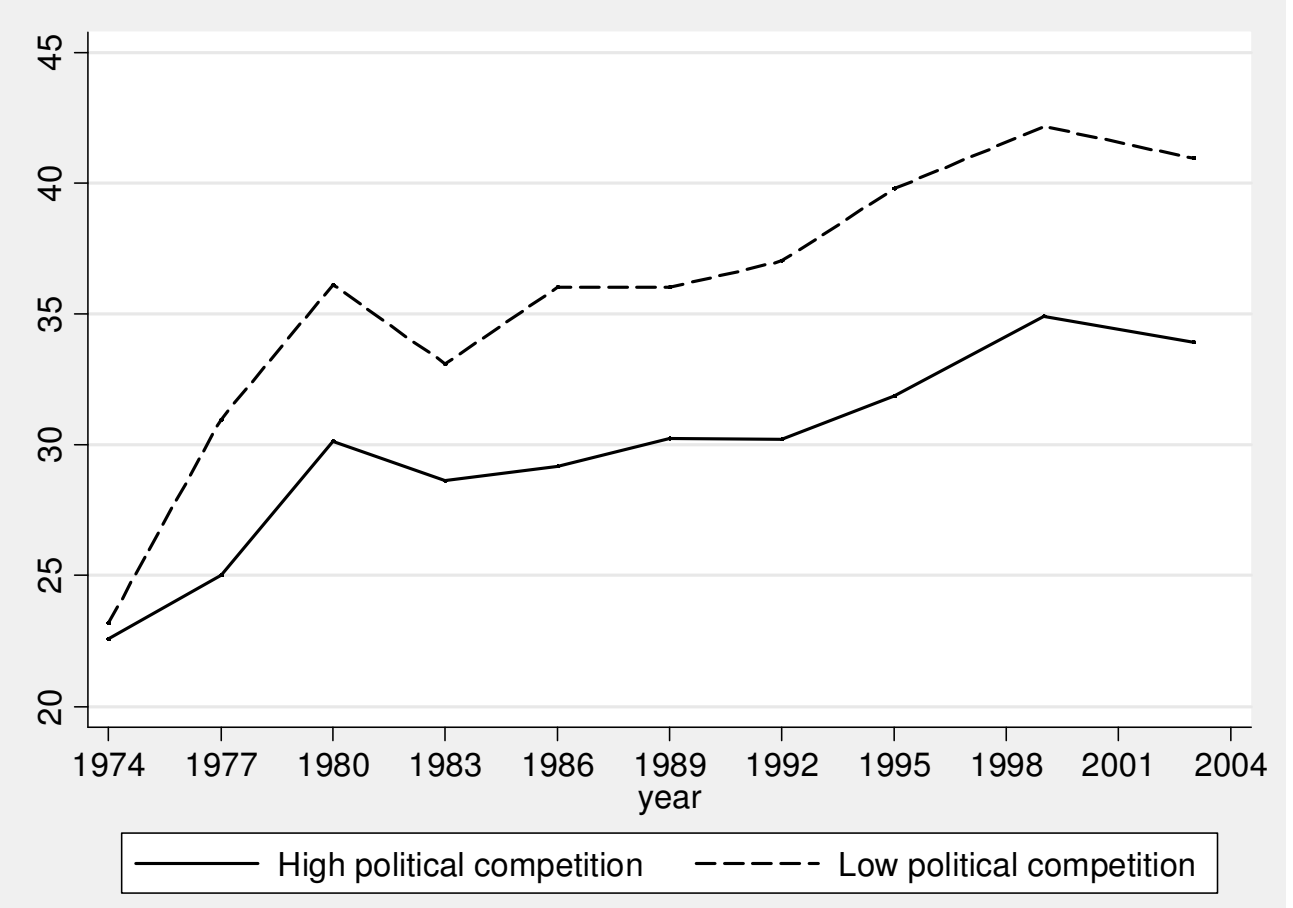

Note: The vertical axis shows municipal-level party support per capita in fixed (2000) prices. High political competition refers to municipalities where the average political competition is above the $75^{\text {th }}$ percentile. Low political competition refers to municipalities where the average political competition is below the $25^{\text {th }}$ percentile. 
Figure 2. The evolution of county-level party support

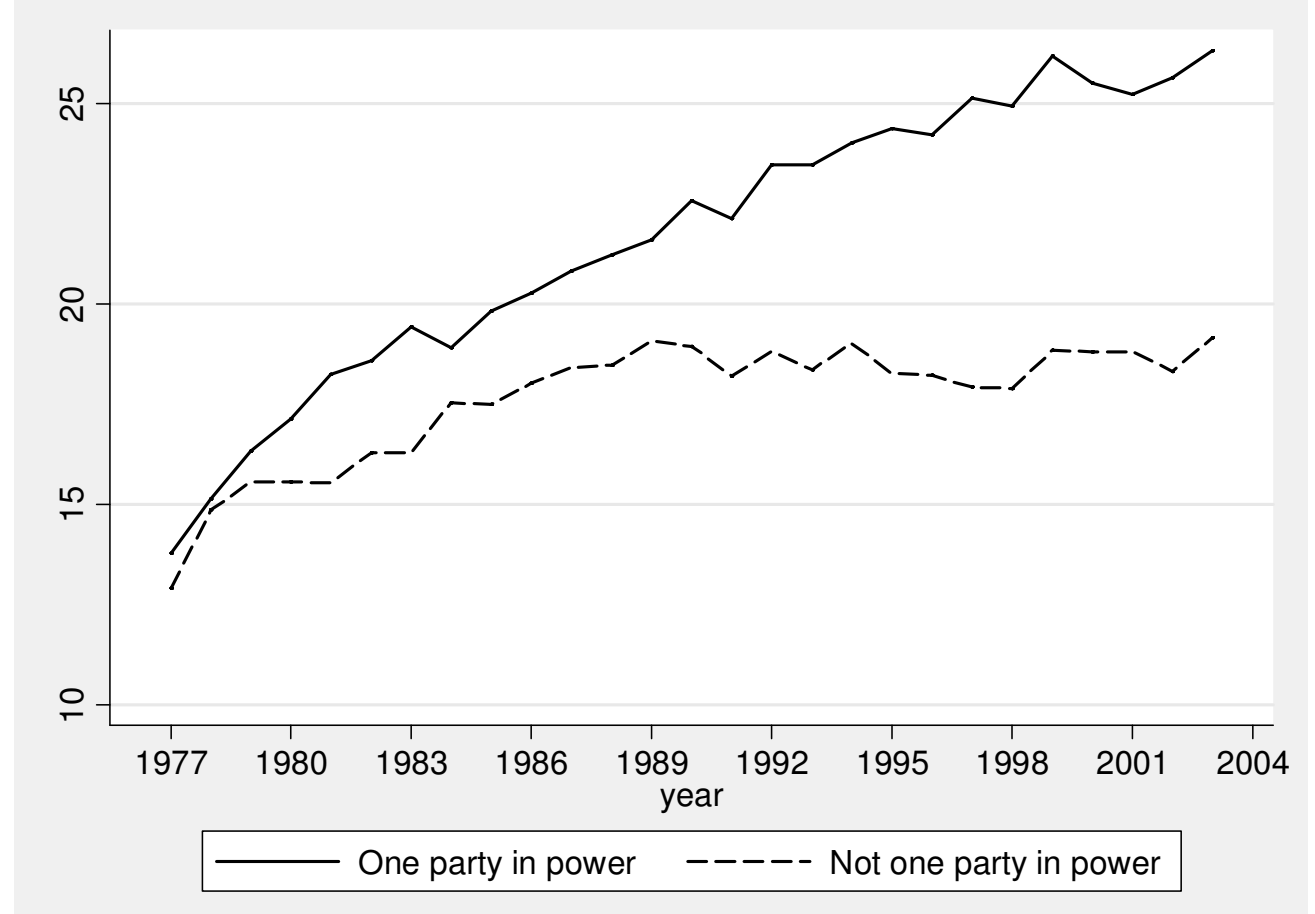

Note: The vertical axis shows council-level party support per capita in fixed (2000) prices. One party in power refers to the eleven counties where one party has been part of the ruling majority throughout the period. Not one party in power refers to the remaining twelve counties. 